UDK 94:327(497.1:497.2)"1927/1928"(093.2)

341.7(497.1:73)"192"(093.2)

Srđan MIĆIĆ

\title{
MISSION OF KONSTANTIN TODOROV IN NORTH AMERICA 1927-1928: YUGOSLAV FOREIGN SERVICE VS. MACEDONIAN-BULGARIAN ORGANISATIONS IN NORTH AMERICA*
}

\begin{abstract}
So-called Macedonian question and the IMRO subversive activities proved to be central issues in YugoslavBulgarian diplomatic relations during interwar period. From the beginning of 1920s, Yugoslav Foreign Service began systematic activity against Bulgarian propaganda in general and in that framework against organisations subordinated to the IMRO in North America. Yugoslav diplomatic-consular service was generally prepared to deal with propaganda activities of Bulgarian state, yet it was to find new solutions applicable in the societies of the United States and Canada, countries with a significant Macedonian Diaspora. Mission of Konstantin Todorov was of great importance as it helped in formulating particular North American strategy in counteracting subversive work of pro-Bulgarian Yugoslav Diaspora.
\end{abstract}

Key words: propaganda, diaspora, Yugoslav-Bulgarian relations, Macedonian question, IMRO

This study aims to explain (extra)institutional framework of activities of the Yugoslav Foreign Service in combating propaganda of both official Bulgaria and the Inner Macedonian Revolutionary Organisation (IMRO) in North America. Within this frame it investigates sequence of events connected with the unofficial mission of Konstantin Vasilev Todorov, an influential figure among Bulgarian agrarians and a close associate of the leader of the agrarian movement Aleksandar Stamboliyski. ${ }^{1}$ Todorov used to be a Bulgarian Plenipotentiary

* This article is result of work on IRHS's research project Serbs in Yugoslav and International Context: Internal Development and Position in European/World Community (No 47027), financed by Ministry of Education, Science and Technological Development of the Republic of Serbia.

1 In this article Bulgarian Cirilic letters are transcribed in the English Latinic as follows: Bulgarian letter „, $\mathcal{K}^{\prime \prime}$ is transcribed as „Zh" in English, Bulgarian letter „ $\breve{\mathrm{H}}^{\prime \prime}$ is transcribed as "Y“ in English, Bulgarian letter "Ц" is transcribed as "ts" in English, Bulgarian letter „"“" is transcribed as „ch“ in English, Bulgarian letter „ш“ is transcribed as „sh“ in Englics, Bulgarian letter "," is transcribed as „ya" in English. 
Minister in Belgrade until the 1923 coup d'état, after which he remained in exile as a political emigrant. Study of Todorov's mission in North America is chosen as the main subject of this paper because it presents an important watershed in shaping particular North-American strategy of Yugoslav authorities in dealing with the subversive Macedonian Diaspora.

Yugoslav-Bulgarian political and diplomatic relations during the interwar period were not in the main focus of Yugoslav or Serbian historiography. There is only one, two-volume collection of papers and several articles on Serbian/Yugoslav-Bulgarian relation in the first half of the twentieth century. ${ }^{2}$ Relations between two South Slavic Kingdoms and the so-called Macedonian question were rather elaborated as a side topic, in the spectrum of broader topics, such as those dealing with Yugoslav-Italian relations in the Balkans, relations between the Balkan states or as a peripheral theme in Yugoslav affairs in Danube region. ${ }^{3}$ This applies also to the particular aspects of the IMRO activities which were studied within more elaborate topics on Yugoslav Foreign Policy and Internal Affairs. ${ }^{4}$ Consequently, the alterations in Yugoslav foreign policy strategies against the IMRO organizational network abroad have never been closely researched by the scholars. Moreover, there is a gap in knowledge concerning differences between Yugoslav Foreign Service activity in continental Europe and the Anglo-Saxon world. ${ }^{5}$ Bulgarian historiography paid much more

2 Jugoslovensko-bugarski odnosi u XX veku, Zbornik radova 1-2, (ur. dr Živko Avramovski), Beograd, 1982; Živko Avramovski, „O stavu jugoslovenske vlade prema devetojunskom prevratu u Bugarskoj 1923. godine“, Zbornik radova „Istorija XX veka“, sveska IX, Beograd, 1968; Иван Ристић, „Дипломатско-конзуларна представништва и представници Краљевинне СХС у Бугарској 1920-1929“, Архив. Часопис Архива Југославије, Година XIII, бр. 1-2, Београд, 2012; Ivan Ristić, „Bugarska politička emigracija u Kraljevini SHS“, Istorija XX veka, Godina XXX, Broj 2, Beograd, 2012; Vladan Jovanović, „Srpski književni glasnik o jugoslovensko-bugarskim odnosima 1920-1930“, Istorija XX veka, Godina XXX, Broj 2, Beograd, 2012.

3 Milan Vanku, Mala Antanta 1920-1938, Titovo Užice, 1969; Dr Desanka Todorović, Jugoslavija $i$ balkanske države 1918-1923, Beograd, 1979; Dr Živko Avramovski, Balkanska antanta (19341940), Beograd, 1986; Дмитар Тасић, „Од демаркационе линије до међународно признате границе - војска и дипломатија у борби за јужне границе Краљевине СХС 1919-1920“, Историја и географија: сусрети и прожимања, Београд, 2014.

4 Vladan Jovanović, Jugoslovenska država i Južna Srbija 1918-1929. Makedonija, Sandžak, Kosovo i Metohija u Kraljevini SHS, Beograd, 2002; Дмитар Тасић, „Војно-политичка акција 'македонствујушчих у Краљевини СХС/Југославији 1919-1934. године“, Архив. Часопис Архива Југославије, Година III, Број 3, Београд, 2002; Дмитар Тасић, Pam после рата. Војска Краљевине Срба, Хрвата и Словенаца на Косову и Метохији и у Македонији 19181920, Београд, 2008.

5 The USA and the United Kingdom were mostly in the scholars' focus related to Serbia in the First World War, work of Peace Conference in Paris, Yugoslav-Italian relations and German menace in the interwar period. Vuk Vinaver, „Engleska i italijansko 'zaokruživanje Jugoslavije' 1926-1928“, Zbornik radova „Istorija XX veka“, sveska VII, Beograd, 1966; Dragoljub Živojinović, Amerika, Italija i stvaranje Jugoslavije, Beograd, 1970; Ivan Čizmić, Jugoslovenski iseljenički pokret u SAD i stvaranje jugoslovenske države 1918, Zagreb, 1974; Dunja Hercigonja, Velika Britanija i spoljnopolitički položaj Jugoslavije 1929-1933. Britanska politika prema jugoslovensko-italijanskim sukobima u vreme svetske privredne krize, Beograd, 1987; Ubavka Ostojić-Fejić, Sjedinjene Američke Države i Srbija 1914-1919, Beograd, 1994. Recently the 
attention to the so-called Macedonian question and activities of the IMRO in Bulgarian-Yugoslav relations. Concerning the IMRO's activity abroad, the main focus was on their activity in Europe and secondary on Bulgarian-Macedonian organizations in North America. ${ }^{6}$

A new regime introduced in Macedonia after the creation of the Kingdom of the Serbs, Croats and Slovenes (Kingdom of SCS) and deterioration of international position and financial situation of Bulgaria after repeated defeats and humiliation experienced in the Second Balkan and Great War, had its repercussion on the character of the Bulgarian state and religious propaganda in 1920s. Under the circumstances, IMRO's activities in Macedonia and abroad had tremendous impact on Yugoslav-Bulgarian relations. ${ }^{7}$

\section{Bulgaro-Macedonian organisations in North America}

Bulgarian and Macedonian Diaspora in North America had organised mutual Bulgaro-Macedonian brotherhoods which were directed by the Bulgaro-Macedonian Committee in Chicago. The most important figure in the Committee was David Nakov, former komitadji from Veles and then priest in Toronto. The Bulgaro-Macedonian Committee and Bulgarian Legation in Washington were engaged in organising and steering Bulgarian propaganda in North America during the First World War and the Peace Conference in Paris;

Yugoslav emigration in the USA and Yugoslav emigration policy were researched by two Serbian historians, Aleksandar R. Miletić, Journey under Surveillance. The Overseas Emigration Policy of the Kingdom of Serbs, Croats and Slovenes in Global Context, 1918-1928, Belgrade, 2009; Vesna Đikanović, Iseljavanje u Sjedinjene Američke Države. Jugoslovensko iskustvo 1918-1941, Beograd, 2012, and several articles were published earlier written by emigrants and Serbian historians in the USA: Alex N. Dragnich, "American Serbs and Old World Politics", Serbian Studies, Vol. 4, No. 3 (Spring 1988); Nicholas Pašić, "Diplomatics Relation between Canada and Serbia", Serbian Studies, Vol. 4, No. 1/2 (Fall/Spring 1986/87), Mirko Dobrijević, "Bishop Nikolai Velimirovich's First Visit to America", Serbian Studies, Vol. 5, No. 2 (Fall 1989).

6 Васил Ал. Василев, Правителството на БЗНС, ВМРО и българо-югославските отношения, София, 1991; Костадин Палешутски, Македонският въпрос в буржоазна Югославия, София, 1983; Любомир Панайотов, Костадин Палешутски, Добрин Мичев, Македония и българско-югославските отношения, София, 1991; Костадин Палешутски, Македонското освободително движение след Първата световна война /1918-1924/, София, 1993; Костадин Палешутски, Македонското освободително движение 1924-1934, София, 1998.

7 More on diverse aspects of the Macedonian question in Yugoslav-Bulgarian relations during 1920's: Dr Desanka Todorović, Jugoslavija i balkanske države 1918-1923, Beograd, 1979; Živko Avramovski, „Makedonsko pitanje u jugoslovensko-bugarskim odnosima od 1918. do 1925. godine", Jugoslovensko-bugarski odnosi u XX veku, Zbornik radova, 1, Beograd, 1980; Dr Živko Avramovski, Balkanska antanta (1934-1940), Beograd, 1986; V. Jovanović, Jugoslovenska država i Južna Srbija; В. А. Василев, Правителствотона БЗНС, ВМРО и българо-югославските отношения; К. Палешутски, Македонският въпрос в буржоазна Югославия; Л. Панайотов, К. Палешутски, Д. Мичев, Македония и българско-югославските отношения; К. Палешутски, Македонското освободително движение след Първата световна война /1918-1924/, София, 1993. 
this was facilitated via pro-Bulgarian political associates of Woodrow Wilson and Bulgaro-Macedonian Diaspora. Their major political accomplishment was a congress in Chicago, organised on behalf of alleged 40,000 BulgariansMacedonians in December 1918. The congress' main propaganda goal was to promote the political program of Bulgaro-Macedonian unification and to raise awareness of both American administration and general public on differences between Serbs, Montenegrins and Bulgarians who were categorized as one entity by US immigration services. ${ }^{8}$ After the First World War, the American government introduced immigration quotas ${ }^{9}$ which decreased BulgaroMacedonian emigration rates from 37,500 in 1912 to 35,000 in $1928 .{ }^{10}$ At the beginning of 1921, the Bulgaro-Macedonian Committee was shivered by strife among members provoked by divisions in the ranks of the IMRO between the so-called "autonomist" and "federalist". ${ }^{11}$ After the end of Woodrow Wilson mandate, pro-Bulgarian propaganda focused attention on the Republican Party which advocated interests of those dissatisfied with decisions of Paris Peace Conference. One of their undisputed accomplishments was the organisation of a lecture entitled "Bulgarian Macedonia" delivered by priest David Nakov in March 1921. The lecture was held in the church of Episcopal Bishop of Harrisburg James Henry Darlington, a great supporter of Serbia and Serbs during First World War. In late 1921 and early 1922, the Bulgaro-Macedonian Committee was establishing contacts with the Croatian, Turkish and Albanian Diaspora in order to organise mutual cooperation on the Yugoslav soil. Allegedly, they collected 50000 \$ the Congress organised in August 1922. ${ }^{12}$

8 Archive of Yugoslavia, Records of the Legation of the Kingdom of Yugoslavia in the United States of America - Washington 371-34-45, 11, 99, 100, 155 (further: AY, 371); Божидар Пурић, Наши исељеници, Београд, 1929, 50; К. Палешутски, Македонското освободително движение след Първата световна война, 13-23, 48, 62; Костадин Гърдев, Българската емиграция в Канада, София, 1994, 50, 56; Михаило Пупин, Национално-политички рад 1908-1935, (приредио проф. др. Драгољуб Р. Живојиновић), Београд, 1998, 132, 133.

9 There were 142,441 of Serbs, Montenegrins and Bulgarians in the United States in 1918. More on quotas immigration policy in the USA and emigration from the Kingdom of SCS: Aleksandar R. Miletić, Journey under Surveillance. The Overseas Emigration Policy of the Kingdom of Serbs, Croats and Slovenes in Global Context, 1918-1928, Belgrade, 2009, 41, 42, 76, 77, 93; Vesna Đikanović, Iseljavanje u Sjedinjene Američke Države. Jugoslovensko iskustvo 1918-1941, Beograd, 2012, 56, 139-141, 196-201, 207, 208.

10 К. Гърдев, op. cit., 48-50, 56, 57.

11 More on fractions in the ranks of the IMRO, their ideas and methods, for further reading: $K$. Палешутски, Македонският въпрос в буржоазна Югославия, 106-108, 112-119; Л. Панайотов, К. Палешутски, Д. Мичев, ор. cit., 48-55, 57, 58; К. Палешутски, Македонското освободително движение след Първата световна война, 39-64, 73-87, 102-110; D. Todorović, op. cit., 39.

12 AY, 371-34-45, 179-183, 191, 192, 199, 200, 214, 215; Archive of Yugoslavia, Records of the General Consulate of the Kingdom of Yugoslavia in New York, 499-13-27 General Consul in New York Pavle Karović to the Ministry of Foreign Affairs, Conf.No.37 from $8^{\text {th }}$ September 1922, General Consul in Chicago Božidar Purić to the Plenipotentiary Minister Ante Tresić-Pavičić and the General Consulate in New York, Conf. No. 119 from $2^{\text {nd }}$ October 1922 (further: AY, 449); Б. Пурић, Наши исељеници, 51, 52; К. Палешутски, Македонският въпрос в буржоазна Югославия, 110-112; К. Палешутски, Македонското освободително движение след Първата световна война, 111, 112. 
The Congress convened in Fort Wayne, $1^{\text {st }}-4^{\text {th }}$ November 1922 , resolved to reorganise the Bulgarian-Macedonian Committee into the Macedonian Political Organisation (MPO). It was the result of a struggle between its two wings, one supporting guerrilla actions of the IMRO and other which only wanted to help propagandistic activities. ${ }^{13}$ The latter group had won and according to the documents delivered by Congress the newly founded organisation could count on the support of around 20,000 members which were obliged to pay 1 $\$$ monthly. Consequently, they were allegedly able to collect $240,000 \$$ annually. Headquarters of the organisation were relocated from Chicago to Fort Wayne, Indiana. ${ }^{14}$ Next year, the annual MPO congress which was held in Indianapolis, $2^{\text {nd }}-7^{\text {th }}$ September 1923 , concluded that the organization had not achieved the planned results. Their assessment was that the main causes for the failure were to be found in the current political situation in Bulgaria and the dissatisfaction of their membership due to maltreatment by IMRO activists. IMRO militants used to collect money by persecuting families of disobedient members of the MPO in South Serbia. In order to consolidate ranks, the Congress decided that the MPO would be independent from and in good relations with Macedonian organisations in Sofia. Estimating that international circumstances were unfavourable for Macedonian independence; Congress proclaimed federalism as the main political goal of the MPO. ${ }^{15}$ The IMRO wanted to prevent distancing of the MPO and had sent Jordan Chkartov with official task to reorganise Bulgaro-Macedonian propaganda in North America. ${ }^{16}$ The struggle between IMRO's autonomists and federalists escalated in open combat after the murder of Alexander Todorov Poprushev on $31^{\text {st }}$ August $1924 .{ }^{17}$

Efforts of the IMRO to take full control over the MPO did not immediately bring expected results. The third annual congress of the MPO held in Fort Wayne, $31^{\text {st }}$ August $-4^{\text {th }}$ September 1924 , confirmed old uncertainties and apathy, and

13 AY, 449-13-27 General Consul in Chicago Božidar Purić to the Plenipotentiary Minister Ante Tresić-Pavičić and the General Consulate in New York, Conf. No.145 from 26 ${ }^{\text {th }}$ October 1922.

14 AY, 371-34-45, 222-224, 276-282, 283; AY, 449-13-27 General Consul in Chicago Božidar Purić to the Plenipotentiary Minister Ante Tresić-Pavičić and the General Consulate in New York, Conf. No. 140 from $20^{\text {th }}$ October 1923; Б. Пурић, Наши исељеници, 52-54.

15 AY, 371-34-45, 311-313, 316-318; AY, 449-13-27 General Consul in Chicago Božidar Purić to the Ministry of Foreign Affairs, Ministry of Interior Affairs, Legation in Washington and consulates in America, Conf. No. 229 from 20 ${ }^{\text {th }}$ September 1923.

16 Jordan Chkartov was born in Prilep, graduated from the Theological High School in Prizren in 1914/1915; he emigrated from Serbia, joined the IMRO and studied law in Hungary and Bulgaria during the occupation of Serbia in the First World War. He was known as good orator and successful agitator. His brother Dimitrije Čkartović remained in the Kingdom of SCS, as a student of technology; he was sentenced to 10 years of imprisonment during trial of students who have organized IMRO's youth in Skopje. AY, 371-34-45, 579; AY, 371-35-46, 116; AY, 44913-27 General Consul in New York Pavle Karović to the General Consulate in Chicago, Conf. No. 88 from $4^{\text {th }}$ September 1924; Archive of Yugoslavia, Records of the Legation of the Kingdom of Yugoslavia in England - London, 341-41 Acting Director of the Political Department of the Ministry of Foreign Affairs Ivo Andrić to the Royal Legations in London, Paris and Washington, Conf. No. 20805 IV Bu.-27 from 26 ${ }^{\text {th }}$ August 1936 (further: AY, 341).

17 К. Палешутски, Македонското освободително движение след Първата световна война, 207-234. 
concluded that seeking support from the Great Powers was unachievable due to different interests of Great Britain, France and Italy in the Balkans. ${ }^{18}$ Finally, victory of autonomists in the ranks of the IMRO in late 1924 and early $1925^{19}$ had its repercussion on the MPO. Jordan Chkartov was elected president of the MPO's Central Committee and continued his activity in privacy, avoiding the public, which made it difficult for the Yugoslavs to continue tracking him. ${ }^{20}$ Meanwhile, the Bulgarian government appointed former komitadji Simeon Radev ${ }^{21}$ to the post of Plenipotentiary Minister in Washington. The main tasks assigned to Simeon Radev were implementation of cooperation between Macedonian and Croatian emigration in North America, continuation of struggle against the MPO's federalist and extension of brotherhoods in Canada. ${ }^{22}$

Work of Jordan Chkartov and Simeon Radev produced results in late 1926 and early 1927. Bulgarian Ministry of Foreign and Religious Affairs organised Section for Macedonian propaganda which was in direct contact with the newly formed Macedonian Press Bureau in New York. ${ }^{23}$ The MPO started to publish newspaper Македонска трибуна in Indianapolis. ${ }^{24}$ The Macedonian Committee in Sofia ordered all subordinated organisations abroad to start intensive anti-Yugoslav propaganda. ${ }^{25}$

18 AY, 371-34-45, 680-685.

19 Костадин Палешутски, Македонското освободително движение 1924-1934, София, 1998, 8-25.

20 AY, 371-34-45, 769, 770.

21 Simeon Radev was born in Struga, educated in Bitolj, Ohrid, Istanbul and Genève; entered diplomatic service in 1913; he was Plenipotentiary Minister in Bucharest and in Berne 1913-1917; resigned from his office in 1917 as an act of protest against the foreign policy of Bulgaria. Reactivated in the Ministry of Foreign and Religious Affairs, as Plenipotentiary Minister in Hague and in Ankara 1920-1925, he was appointed to Washington in 1925. He was member of several Bulgarian delegations: in Bucharest in 1913, in Thessalonica in 1918, in the League of Nations in 1922. As a journalist had active role in Bulgarian propaganda until 1913, and his most significant work was La Macédonie et la Renaissanse Bulgare au XIX-ème siècle, published in Sofia in 1918. Симеон Радев, История и личности. Политически портрети на Лойд Джордж, Джозеф, Остин и Невил Чембърлейн, Пол Думер, Аристид Бриян, Джозеф Кайо, Франческо Нити, Густав Щреземан. (Из документалното наследство), (със.Цочо В. Билярски), София, 2011, 6-10; Трето Българско Царство 1879-1946. Историческа Енциклопедия, (Атанас Тошкин, Ана Рабаджийска, Милен Куманов), София, 2003, 309.

22 AY, 371-34-45, 801, 808; AY, 449-13-27 circular letter of Plenipotentiary Minister Ante TresićPavičić to the consulates, Conf. No. 170 from $18^{\text {th }}$ June 1925.

23 Macedonian Press Bureau was led by Lambo Kiselinchev and Nikola Mitrov. Nikola Mitrov was born in Prilep; he had contacts with Macedonian committee in Sofia until the Balkans wars. He was volunteer in the Serbian Army until 1915, served in the Bulgarian army 1915-1918. He had rescued 700 Serbs in Prilep from Bulgarian massacre during the First World War and returned to Prilep after 1918. He emigrated to Czechoslovakia and France while refusing to be recruited in the Yugoslav army and did not obtain a state scholarship for studies in Prague. In France Nikola Mitrov reestablished contacts with the IMRO, while helping the Yugoslav Legation in Paris support emigration from South Serbia to North America. Utilizing his connections with Macedonian emigration, the IMRO appointed him to Macedonian Press Bureau in New York. AY, 371-35-46, 91, 140-144.

24 AY, 371-35-46, 89; AY, 449-13-27 Legation in Washington to the General Consulate in New York, Conf. No. 129 from $22^{\text {nd }}$ April 1927.

25 AY, 449-13-27 circular letter of the Legation in Washington to all consulates, Conf. No. 48 from $21^{\text {st }}$ April 1927. 
Until 1927, Bulgarian propaganda and the IMRO were striving on taking control over political organisation of Macedonian Diaspora. After several noticeable results achieved since 1918, divisions amid the IMRO had endangered their influence. Macedonian Diaspora had showed intention to use that situation and take a more independent position. When the IMRO had overcame its inner strife they reclaimed their dominance in the ranks of Macedonian diaspora with support of Bulgarian Ministry of Foreign and Religious Affairs.

\section{Yugoslav diplomatic-consular service in North America}

The Kingdom of Serbs, Croats and Slovenes had inherited from the Kingdom of Serbia the Legation in Washington and began establishing its consular network in the USA during 1919-1920 establishing consulates in New York, Chicago and San Francisco. Also, former Montenegrin Consul in Montreal Anto Seferović had entered the Yugoslav diplomatic-consular service. Due to the lack of adequate funding, both the intelligence and propaganda activities of the diplomatic-consular service were based primarily on personal contacts and collaboration with individuals and organisations founded by Yugoslav Diaspora loyal to Yugoslav authorities. ${ }^{26}$ Main intelligence tasks were designated to General Consulate in Chicago, since main strongholds of Bulgarian-Macedonian organisations in the USA were located on the territory under its jurisdiction.

According to information provided by the Yugoslav Legation in Washington in June 1920, Bulgarian propaganda in the USA virtually did not exist since the beginning of $1919 .{ }^{27}$ The first problems in the confrontation with pro-Bulgarian activity of Macedonian Diaspora were encountered no earlier than in March-April 1921. Ethnic Macedonians in the USA played an important role among Bulgarian Diaspora. Not only were they entirely dedicated to the political aims of Bulgaria but they appeared to be a vanguard and the most important driving force of the Bulgarian organisations. Acting on the received report by General Consul in Chicago Branko Lazarević ${ }^{28}$ which elaborated on ongoing political frictions among

26 Божидар Пурић, Биографија Боже Ранковића. Допринос историји српског исељеништва у Северној Америци, München, 1963, 157, 161.

27 AY, 371-34-45, 136.

28 He was the son of Đorđe Lazarević an industrialist from Negotin and son in law of Chief of States Monopolies in Belgrade Raša Milošević. Branko Lazarević served in the Army 19121916; appointed Chief of Press Bureau of the Ministry of Foreign Affairs and was editor of the official Српске новине from 1916. He was appointed Secretary at the Legation in Tokyo and Secretary at the Legation in Washington. Referent of Arts Department of Ministry of Education, by the Decree in November 1919, which was annulled at the beginning of April 1920 due to his persistent opposition. During February 1920, he was assigned to the Legation in Washington Press Bureau. Appointed General Consul in Chicago, on $16^{\text {th }}$ June, dismissed in Washington on $30^{\text {th }}$ July, and took office on $12^{\text {th }}$ August 1920 . He was General Consul in Chicago until the end of May 1922. Archive of Yugoslavia, Records of the Ministry of Foreign Affairs, Personnel Section, 334-165-488, 373 (2, 3), 375, 376, 381, 386-394, 397-401, 405 (further: AY, 334-Personnel). 
Macedonian Diaspora, Minister of Foreign Affairs Nikola Pašić issued an order to the Legation in Washington in March 1921, to use the situation in order to win over some of the fractions for the Kingdom of SCS. ${ }^{29}$ In April 1921, Branko Lazarević sent detailed analyses of the existing situation in the Bulgarian-Macedonian Committee and perspectives for counteraction to the Legation in Washington. He defined as one of the key issues the separation between Serbian and Macedonian Diasporas in the USA. This was a problem for Yugoslav Foreign Service which was relaying on the cooperation of the emigrants loyal to the Kingdom of SCS. Branko Lazarevic had estimated that not more than 3,000 members of the Bulgarian-Macedonian Committee were Bulgarian subjects and 37,000 came from so-called South Serbia and Aegean Macedonia. According to his report, one and only favourable circumstance was lack of enthusiasm of the Macedonian emigrants for donating money for the purpose of guerrilla warfare in South Serbia. ${ }^{30}$

Dissolution of the Bulgarian-Macedonian Committee and formation of the MPO brought alarming news to representatives of the Kingdom of SCS. Although the MPO had 20,000 fewer members than the Bulgarian-Macedonian Committee, the Yugoslav Foreign Service was worried by the amount of money which the MPO could allegedly collect for actions on Yugoslav soil. ${ }^{31}$ Legation of the Kingdom of SCS in Washington had concluded that it was not enough only to track the organisation's work, but they were to neutralise it; on this particular issue they asked for an opinion from General Consulate in Chicago. ${ }^{32}$ General Consul Božidar Purić ${ }^{33}$ replied on $2^{\text {nd }}$ November $1922^{34}$ that most of

29 AY, 371-34-45, 152.

30 АY, 371-34-45, 155, 156; Б. Пурић, Наши исељеници, 50, 51.

31 General Consul in Chicago Božidar Purić warned the Ministry of Foreign Affairs on the threat imposed by Bulgarian propaganda in North America, and based his argumentation on gathered and confirmed data that the MPO was able to collect a sum of 240,000 \$. AY, 449-13-27 General Consul in Chicago Božidar Purić to the Political Department of the Ministry of Foreign Affairs and the General Consulate in New York, Conf. No. 29 from $29^{\text {th }}$ January 1923. In comparison, Serbs in North America had collected for the Serbian Red Cross 310000 \$ throughout 19121915. Alex N. Dragnich, "American Serbs and Old World Politics", Serbian Studies, Volume 4, Number 3, (Spring 1988), 8.

32 AY, 371-34-45, 224.

33 Son of a merchant Luka Purić, born in Belgrade, graduated from the Law School in Paris in 1912.; was a volunteer in the First Balkan War; was recruited into the IV cavalry regiment under command of Lt. Col. Petar Živković in the First World War 1914-1916; served in Serbian Volunteers Corpus in Romania and Russia in 1916; assigned to the Ministry of Foreign Affairs in 1917; doctorate of jurisprudence in Paris in 1918; appointed Secretary of the Legation in Washington and immediately sent as Chargé d'Affaires to Russia in November 1919; returned to the United States as Consul in Chicago and took office in the General Consulate in San Francisco in October 1920. Appointed General Consul in Chicago on $6^{\text {th }}$ April, replaced Branko Lazarević in May 1922. Although he had misunderstandings with Plenipotentiary Minister in Washington, Ante Tresić-Pavičić acknowledged his prominence in countering enemy propaganda. AY, 334-Personnel-165-488, 403; AY, 334-Personnel-171-493, 812; AY, 334-Personnel-183-509, 26 (1-4), 27, 29-35, 40-52, 73, 74.

34 Božidar Purić obtained original text of the MPO Charter and Memorandum sent from Congress in Fort Wayne to Stjepan Radić in December. AY, 449-13-27 General Consul in Chicago Božidar Purić to Ante Tresić-Pavičić and the General Consulate in New York, Conf. No. 170 from 9 $9^{\text {th }}$ December 1922. 
the Macedonians in the USA were neither ethnic Bulgarians nor so-called bulgarophils (“бугараши"), but persons who were for many years actually "trembling" in fear of the Bulgarian, Serbian and Greek guerrilla ("чета") and Ottoman authorities in Macedonia, and who were used to being robbed and maltreated by all sides. Therefore, he concluded that the Macedonian emigrants were only loyal to the MPO out of fear of the IMRO's persecution of their families in South Serbia. Purić saw them as "mentally exhausted" people who only sought to live peacefully and to be protected from maltreatment of all the agitators. Therefore he marked their liberation from "slave's psychology and mentality" as one of the main goals of the activities of diplomatic-consular representatives in North America and state institutions in the Kingdom of SCS. He proposed four basic principles for actions:

1. Fear from the IMRO should be parried by fear from Yugoslav authorities; this was to be brought about by capturing and prosecuting emigrant couriers who were transferring money from North America to Macedonia and by seizing IMRO's archives, as a distinctive message that anti-Yugoslav activities shall not be tolerated;

2. Restoration of Serbian National Defence (SND) organization network in North America which was to be assigned to provoke incidents during the public rallies of Bulgarian-Macedonian brotherhoods;

3. To publish and to distribute brochures and pamphlets written by Yugoslav experts but printed in the Bulgarian language and under false authorship of former distinguished Bulgarian national propagandists;

4. Winning over hearts and minds of both the Bulgarian agitators and Macedonian emigrants.

Interestingly, the General Consul's estimation was that a small amount of no more than 150 \$ monthly should be an adequate sum to sponsor these activities. Plenipotentiary Minister in Washington Ante Tresić-Pavičić agreed with the proposed plan for action and recommended it to the Ministry of Foreign Affairs. ${ }^{35}$

In his next report, sent also on $2^{\text {nd }}$ November, Božidar Purić proposed to Ante Tresić-Pavičić to organize a conference in Washington with all consuls or at least heads of missions in Chicago and New York. He pointed out the bad administrative organization of diplomatic-consular missions, which according to him, could cause bigger problems than an acute lack of funds. He thought that they should reorganize work in the Consulates and the Legation in such a way that every clerk was paid according to his achievements and to use the rest of the money to counter enemy propaganda. General Consul underlined

35 AY, 371-34-45, 226, 227; AY, 449-13-27 General Consul in Chicago Božidar Purić to the Plenipotentiary Minister Ante Tresić-Pavičić and the General Consulate in New York, Conf. No.149 from $2^{\text {nd }}$ November 1922. 
that Ministry of Foreign Affairs had never consulted them on the needs of diplomatic-consular service and value of provided personnel, "but that it was appointing useless clerks allowing them high salaries". General Consul in New York, Pavle Karović, supported the proposition to organize a three-partite diplomatic-consular conference in Washington in order to formulate a plan for counteractions against enemy propaganda, but the Legation in Washington did not have sufficient funds to organize it. ${ }^{36}$

According to archival records, the Ministry of Foreign Affairs issued an order, for the first time, to diplomatic and consular representatives not only to trail Bulgarian activities but to take adequate measures to suppress Bulgarian propagandists in February 1923. Deputy Minister Panta Gavrilović in his instructions interpreted views adopted by ministries of foreign and interior affairs on the Macedonian population: present Macedonian Diaspora was not aware of the new situation of personal security and rule of law which was allegedly established in South Serbia because in the past they had been under constant influence of "different terroristic committees" and they cannot perceive that the situation changed. Therefore, both Ministries thought that ethnic Macedonian Diaspora did not understand that anti-state activities could only harm them and their families. Ministry of Interior took the standpoint that the Macedonian Diaspora was working in the service of Bulgarian propaganda only under pressure and threats from the IMRO. ${ }^{37}$ General Consulate in New York replied to the Deputy Minister that they could not counter Bulgarian activity without adequate funds. ${ }^{38}$

Yugoslav Foreign Service achieved its first results in Canada in April 1923, based on Božidar Purić's propositions. Namely, the Consulate in Toronto and General Consulate in Montreal with assistance of General Secretary of the SND

36 Ante Tresić-Pavičić could not persuade Ministry of Foreign Affairs to send him money for the conference with consuls from New York, Chicago and San Francisco, and proposed in October 1923 that four missions should exchange monthly reports. AY, 449-16-39 General Consul in Chicago Božidar Purić to the Plenipotentiary Minister Ante Tresić-Pavičić and the General Consulate in New York, Conf. No. 150 from $2^{\text {nd }}$ November 1922, General Consul in New York Pavle Karović to the Plenipotentiary Minister Ante Tresić-Pavičić, New York $25^{\text {th }}$ January 1923, General Consul in Chicago Božidar Purić to the Plenipotentiary Minister Ante Tresić-Pavičić and the General Consulate in New York, Conf. No. 24 from 29 ${ }^{\text {th }}$ January 1923, Plenipotentiary Minister Ante Tresić-Pavičić to the General Consulates in New York and Chicago, Conf. No. 41 from $7^{\text {th }}$ February 1923, Plenipotentiary Minister Ante Tresić-Pavičić to the Consulate in San Francisco and General Consulate in New York, Conf. No. 402 form $20^{\text {th }}$ October 1923.

37 Due to partially preserved records of the Ministry of Foreign Affairs and the Ministry of Interior Affairs, the author of this article was not in a position to deduct if the ministries had come to the same conclusions as Božidar Purić through analyses based on information gathered from several sources or if the ministries had merely accepted the viewpoints of General Consul in Chicago. AY, 449-13-27 Deputy Minister of Foreign Affairs Panta Gavrilović to the General Consulate in New York, Conf. No. 1725 from 23 ${ }^{\text {rd }}$ February 1923.

38 AY, 449-13-27 General Consulate in New York to the Deputy Minister Panta Gavrilović, with no Register No and date. 
Božidar M. Marković39 and Đorđe Jonić provoked a conflict between priest David Nakov and his parishioners, which occurred after David Nakov had been recalled and a new priest Velik Karadzhov had been appointed. ${ }^{40}$ Up until then, Canadian authorities did not respond to Yugoslav interventions against emigrants' gatherings, because there were no violations of proclaimed law and state order. The SND's task was to provoke incidents at meetings and thus force police intervention in order to preserve public order. First physical confrontation and police intervention took place during assembly of the Bulgarian-Macedonian brotherhood "Justice" under presidency of priest David Nakov. Božidar Marković proposed to win over David Nakov for the Kingdom of SCS, after he had lost his parish and income, and moved to the USA. Although his proposition was compatible with Božidar Purićs plan, General Consulate in Montreal was sceptical about the loyalty of a person who would work only for money. ${ }^{41}$

After the first positive results, Legation in Washington demanded the consulates in North America take further actions against Bulgarian agitation and win the loyalty of Macedonian Diaspora. ${ }^{42}$ Since the Ministry of Foreign Affairs had not responded to the proposition that three-partite conference of plenipotentiary minister and general consuls should be organised in Washington, General Consul in New York Pavle Karović ${ }^{43}$ proposed to Deputy Minister Panta Gavrilović that Ante Tresić-Pavičić, Božidar Purić and himself should come to Belgrade to submit their reports on hitherto actions and receive new instructions. He also asked for permission to take two months leave in Belgrade as his intention was to acquire detailed knowledge on the attitudes of the Ministry of Foreign Affairs toward the main issues and counteraction against Bulgarian-Macedonian and Montenegrin emigration. ${ }^{44}$ This proposition was rejected by Panta Gavrilović who thought it would not be wise to leave the most important diplomatic-consular missions in the US without their chiefs. ${ }^{45}$

39 Božidar M. Marković was the most reliable confidant of General Consulate in Montreal. He used his acquired social status as manager in a textile factory in Toronto and joined the Canadian Conservative Party in order to expand acquaintances and rival the Bulgarian-Macedonian emigration in political circles. AY, 341-23-54 General Consul in Montreal Anto Seferović to the Royal Legation in London, Conf. No. 49 from 19 ${ }^{\text {th }}$ March 1930; AY, 371-44-59, 454.

40 AY, 371-34-45, 286, 289-292; AY, 341-41 General Consul in Montreal Anto V. Seferović to the Political Department of Ministry of Foreign Affairs, Conf. No. 160 from $5^{\text {th }}$ September 1923.

41 AY, 371-34-45, 302-309; AY, 371-44-59, 455.

42 AY, 449-13-27 Legation in Washington to the General Consulate in New York, C. No. 66 from $12^{\text {th }}$ April 1923.

43 Pavle Karović was born and educated in Belgrade, doctoral of jurisprudence acquired in Paris in 1912, started his career in Trial Court in Belgrade 1912, was transferred to Ministry of Foreign Affairs in May 1914. He was a member of Delegation of the Kingdom of SCS on the Peace Conference in Paris, 1918-1920. Due to his knowledge of the English and German language, he was posted in London, the Hague and New York, during 1915-1926. He was appointed General Consul in New York on $31^{\text {st }}$ August 1921. AY, 334-Personnel-160-483, 575 $(4,5), 576,579,584,585,592,597,599$.

44 AY, 334-Personnel-160-483, 593, 594.

45 AY, 449-16-39 Deputy Minister of Foreign Affairs Panta Gavrilović to the General Consulate in New York, Per. Conf. No. 1902 from 18 ${ }^{\text {th }}$ May 1923. 
Ministry of Foreign Affairs once more issued an order to the diplomatic and consular representatives to take adequate counter measures against Bulgarian propaganda in January $1924 .{ }^{46}$ On the other hand, Božidar Purić in order to implement the first point of his plan sent to the Ministry of Foreign Affairs a list of all members of the MPO who had families and relatives in South Serbia in April 1924. ${ }^{47}$ Ante Tresić-Pavičić and Božidar Purić concluded in the summer 1924, that Bulgarian-Macedonian propaganda was growing stronger. ${ }^{48}$ Plenipotentiary Minister was referring to insufficient funds for counter action and was recommending closer collaboration with the Serbian clergy. General Consulate in Chicago proposed that General Consulates in New York and Montreal should work harder because half of MPO's branches were on territory under their jurisdiction. According to his analyse 2/3 of their membership were immigrants from South Serbia and Aegean Macedonia, which was a decline in numbers and percentage in comparison with their actual influence within the Bulgarian-Macedonian committee but the MPO was still perceived as far more dangerous. Božidar Purić proposed that diplomatic-consular service should win over confidants in each of the Bulgarian-Macedonian brotherhoods. ${ }^{49}$ General Consul in Montreal Anto Seferović replied that Ministry of Foreign Affairs did not accept his numerous propositions on methods for winning over Canadian authorities to support Yugoslav Foreign Service against Bulgarian propaganda and that he had spent more than 6,000 of his own money in his counterwork. ${ }^{50}$

Božidar Purić received report in April 1924 that only one BulgarianMacedonian brotherhood in Pennsylvania had been able to raise over 4,800 $\${ }^{51}$ This report seemed to confirm earlier knowledge of Yugoslav Foreign Service on the strength of the MPO. Nevertheless, in the second half of 1924, General Consul in Chicago gathered data on the failure of Bulgarian agitation concerning collection of money for the work of the IMRO. After the First Annual Congress of the MPO held in September, he reported that they had not gathered more than 5,000 \$ which was by far a lesser sum than the anticipated $240,000 \$ .^{52}$ In December 1924,

46 AY, 371-34-45, 411, 412.

47 AY, 449-13-27 General Consul Božidar Purić to the Political Department of the Ministry of Foreign Affairs and the General Consulate in New York, Conf. No. 108 from $4^{\text {th }}$ April 1924.

48 AY, 449-11-25 Gordon Gordon-Smith to the Pavle Karović, 23 ${ }^{\text {rd }}$ October 1923; Press Department of the Ministry of Foreign Affairs to the General Consulate in New York, Conf. P. D. No. 285 from 29 $9^{\text {th }}$ June 1924; General Consulate in New York to the Legation in Washington, Conf. No. 75 from $6^{\text {th }}$ August 1924; Legation in Washington to the General Consulate in New York, Conf. No. 484 from $8^{\text {th }}$ August 1924; General Consulate in New York to the Legation in Washington, Conf. No. 78 from $11^{\text {th }}$ August 1924; Legation in Washington to the General Consulate in New York, Conf. No. 489 from $15^{\text {th }}$ August 1924.

49 AY, 371-34-45, 609-615; AY, 449-13-27 Plenipotentiary Minister Ante Tresić-Pavičić to the General Consulates in New York and Chicago, Conf. No. 165 from $17^{\text {th }}$ August 1924.

50 AY, 371-44-59, 440-443.

51 AY, 449-13-27 General Consul Božidar Purić to the General Consulate in New York, Conf. No. 111 from $24^{\text {th }}$ April 1924.

52 AY, 449-13-27 General Consul in Chicago Božidar Purić to the Ministry of Foreign Affairs, Ministry of Interior Affairs, Legation in Washington and consulates in America, Conf. No. 229 from $20^{\text {th }}$ September 1923. 
Božidar Purić had confirmed his earlier conclusion. He compared the efficiency of the American Red Cross and the Bulgarian-Macedonian brotherhoods, since both organisations were raising funds for the Macedonian and Thracian refugees in Bulgaria. The American Red Cross managed to gather 10,000 \$ and Bulgarian and Macedonian Diaspora collected 2,560 \$, and Božidar Purić saw it as proof that the MPO was not as strong as it was anticipated..$^{53}$

In December 1924, Plenipotentiary Minister Ante Tresić-Pavičić asked consulates in the USA to send him detailed reports on the most important issues which preoccupied Yugoslav Foreign Service on account of its five-year experience. One of the raised issues was activity against enemy propaganda. ${ }^{54}$ In their replies general consuls in New York and Chicago had submitted detailed conclusions regarding counteractions versus Bulgarian propaganda on territories under their jurisdiction. Božidar Purić had repeated information from his earlier reports that the MPO had not more than 1000 members in the USA, of whom 2/3 were from Aegean Macedonia. According to his report, General Consulate in Chicago had managed to achieve good results among Macedonian Diaspora owing to the support by and cooperation with the Serbian clergy and Diaspora loyal to the Yugoslav state. ${ }^{55}$ Pavle Karović reported that Bulgarian-Macedonian work had more success in the ranks of Macedonian Diaspora than in American public. General Consulate in New York was focused on intelligence because they had limited means to counter them. Therefore, Pavle Karović proposed focusing on cooperation with Serbian clergy and Yugoslav authorities in South Serbia, while lack of sufficient funds did not allow them to develop any propaganda or confidants network on American soil. ${ }^{56}$

In January 1925, General Consul Pavle Karović proposed opening of the Press Bureau in New York, yet Ante Tresić-Pavičić did not agree because it could be used only for propaganda and not for intelligence work. ${ }^{57} \mathrm{New}$ difficulty was

53 AY, 449-13-27 Božidar Purić to the Political Department of Ministry of Foreign Affairs and General Consulate in New York, Conf. No. 419 from 23 ${ }^{\text {th }}$ December 1924; General Consul Božidar Purić to the Legation in Washington and General Consulate in New York, Conf. No. 172 from $7^{\text {th }}$ April 1925.

54 AY, 449-16-37 circular letter of Plenipotentiary Minister Ante Tresić-Pavičić to Consulates, Conf. No. 663 from $10^{\text {th }}$ December 1924.

55 AY, 449-136-37 General Consul in Chicago Božidar Purić to the Royal Legation in Washington and General Consulate in New York, Conf. No. 19 from $2^{\text {nd }}$ February 1925.

56 AY, 449-16-37 General Consul in New York Pavle Karović to the Legation in Washington, Conf. No. 38 from $17^{\text {th }}$ February 1925.

57 AY, 449-11-25 General Consul Pavle Karović to the Press Department of the Ministry of Foreign Affairs, C. No. 117 from 22 ${ }^{\text {nd }}$ December 1924; General Consulate in New York to the Legation in Washington, Press Department and Political Department of the Ministry of Foreign Affairs, No. 122/25 from 22nd January 1925; Plenipotentiary Minister Ante Tresić-Pavičić to the General Consulate in New York, Conf. No. 15 from 30 ${ }^{\text {th }}$ January 1925; General Consul Pavle Karović to the Legation in Washington, from $5^{\text {th }}$ February 1925; Ante Tresić-Pavičić to the Political Department of the Ministry of Foreign Affairs, Conf. No. 130 from 27 $7^{\text {th }}$ April 1925. Press Department of the Ministry of Foreign Affairs considering mailing reports directly to interested persons because the American public did not appreciate the European practice of conducting propaganda through diplomatic-consular missions in 1924. AY, 449-11-25 Press Department of the Ministry of Foreign Affairs to the Royal Consulate in Pittsburgh, Conf. P. D. No. 295 from 30 ${ }^{\text {th }}$ June 1924. 
the resignation of State Secretary Charles Evans Hughes, Sr. in January 1925, who supported Yugoslav propaganda against Bulgaria and Italy through semiofficial Washington Post. ${ }^{58}$ Yugoslav authorities introduced new emigration policy in South Serbia, due to the doubtful loyalty of Macedonian Diaspora. Local authorities in South Serbia were issuing individual permissions for each emigrant since 1925. ${ }^{59}$ With reference to the new Bulgarian Plenipotentiary Minister in Washington Simeon Radev, who was appointed in 1925, Yugoslav authorities had received warning from several sources. Bulgarian Extraordinary Envoy in Prague Dimitar Mihalchev ${ }^{60}$ depicted him as unscrupulous complotter for whom the end justified any mean. ${ }^{61}$ Yugoslav Ministry of Internal Affairs had an intelligence report that Simeon Radev had taken part in IMRO's Congress incognito, without knowledge of Bulgarian Ministry of Foreign and Religious Affairs in April 1925. ${ }^{62}$

Bulgarian propaganda efforts were appraised by Yugoslav diplomaticconsular service as unsuccessful during 1926. In late 1926 and early 1927, Yugoslav Ministry of Foreign Affairs replaced its personnel in the USA almost simultaneously with the first significant results of Bulgarian propaganda conducted by Simeon Radev and Jordan Chkartov. Božidar Purić was appointed General Political Director of the Ministry of Foreign Affairs, Vojislav Antonijević ${ }^{63}$

\section{AY, 371-34-45, 469.}

59 The Kingdom of SCS at first supported emigration of non-Slavs, and in South Serbia authorities were considering political and economic aspects of workforce departure in 1920. Since 1921 state institutions have started to think on issues of loyalty and new criterion was introduced in 1923, when each case was examined individually. A. Miletić, op. cit., 109, 110, 118; V. Đikanović, op. cit., 170, 173, 174, 179, 180. Legation in Athens was assigned to prevent emigration from South Serbia via Piraeus organised by Macedonian Committee in Sofia since 1927. AY, 334-Personnel-53-145, 644; Archive of Serbia, Collections of the Security Information Agency, List IV, Record No. 41, page 56.

60 Dimitar Mihalchev was born in Lozengrad, studied philosophy in Sofia, Berlin, Greifswald, Freiburg and Munich; was professor at University of Sofia; member of delegation which has signed the Peace Treaty of Neuilly-sur-Seine and Plenipotentiary Minister in Prague 1923-1927. He had close collaboration with president of Czechoslovakia Tomáš Garrigue Masaryk on realization of Bulgarian-Yugoslav cooperation. In his works, Dimitar Michalchev highlighted cultural similarities amid South Slavs, avoiding national and ethnical similarities and differences. Трето Българско Царство 1879-1946, 244; Георги Белогашев, „Димитър Михалчев и 'идеята за интегрална Югославия'”, Философски алтернативи, кн. 2, София, 2010; Георги Белогашев, „Идеята за интегрална Югославия и нейното философско осмисляне“, България и Балканите в сферата на европйските влияния през ХІХ-ХХІ век, Сборник статии, Велико Търново, 2012.

61 AY, 371-34-45, 778, 779, 801, 808.

62 Archive of Yugoslavia, Records of the Ministry of Internal Affairs of the Kingdom of Yugoslavia 14-29-80, 277, 278.

63 Vojislav Antonijević attended Gymnasiums in Kragujevac and Belgrade; was journalist in Новине Србпске; entered the diplomatic service as clerk in Serbian Legation in London 1902; promoted to Secretary in the Ministry 1911. He was Plenipotentiary Minister in Rome 1914-1926, appointed Plenipotentiary Minister in Washington in 1927. Ko je ko u Jugoslaviji, Beograd-Zagreb, 1928, 8; Српски биографски речник, 1, Нови Сад, 2004, 219; Српска енциклопедија, Том I, Књига I, Нови Сад - Београд, 2010, 264. 
Plenipotentiary Minister in Washington, Dr Đorđe Todorovićc4 General Consul in New York and Radoje Janković ${ }^{65}$ General Consul in Chicago. These changes may appear random, yet it is indicative that the new Extraordinary Envoy in Washington was for years Plenipotentiary Minister in Rome, new General Consul in New York was former Head of the Political Department of the Ministry of Foreign Affairs, and new General Consul in Chicago was earlier member of organisation "Unification or Death", familiar with conspiratorial manners which were characteristic for the activities of the IMRO. Analysing gathered data, the new General Political Director of the Ministry of Foreign Affairs Božidar Purić concluded that the thorough organisation of Bulgarian propaganda and achieved results were not a result of policies conducted by Bulgaria and Macedonian organisations, yet were primarily a result of Italian propaganda and policy in the Balkans as well as Italian financial support to various anti-Yugoslav and proItalian organisations, after signing Italian-Albanian Pact of mutual friendship and security on $27^{\text {th }}$ November 1926 . He concluded that the Italians were a far more influential factor in relation to the MPO than Jordan Chkartov or Simeon Radev. Ministry of Foreign Affairs received reports that Italy was financing Macedonian Press Bureau in New York and Македонска трибуна in Indianapolis. ${ }^{66}$

64 Đorđe V. Todorović was the son of former Serbian Minister and Senator Velimir Todorović; he had graduated and received his PhD from the Faculty of Law in Paris; entered diplomatic service and appointed Secretary of the Legation in London 1914; Secretary in the Ministry of Foreign Affairs 1916-1917; Secretary of Serbian Legation in Washington 1917-1919. He was Director of Administrative and Legal Department and Director of Political Department in the Ministry of Foreign Affairs 1922-1923. Đorđe Todorović was appointed as Counselor at the Legation in London, 1924-1926. Promoted to General Consul in New York on 24 $4^{\text {th }}$ October 1926 and took new office on $12^{\text {th }}$ January 1927. AY, 334-Personnel-196-519, 401-404, 413, 415, 417, 421, 424, 427, 429, 432; AY, 449-16-39 Chief of the Personnel Section of the Ministry of Foreign Affairs Dr. Vladimir Kojić to the Royal General Consulate in New York, Per. Conf. No. 4111 from $26^{\text {th }}$ October 1926, Consul in New York to the Legation in Washington, Ref. Conf. No. 6 from $12^{\text {th }}$ January 1927.

65 Radoje Janković completed six grades of high school in Čačak and continued his education at Lower and Higher School of the Military Academy in Belgrade and Intendants School at Military Academy in Paris. He served in the infantry and in cavalry; was part time professor at High School of Military Academy in Belgrade; one of the founders of Pijemont, associates of Време, Српски књижевни гласник, Војска аnd other journals. As a member of organization "Unification or Death", also known as the "Black Hand", he was retired in the rank of infantry Major due to verdict delivered at the Thessaloniki trial while he served in volunteer units in Russia in 1917. Thereafter, he was a political emigrant in Russia, Italy, France and Austria until 1923. He served prison sentence in the Kingdom of SCS until he was pardoned in 1925. Special meeting held in the Ministry of Foreign Affairs, on $16^{\text {th }}$ May 1926, decided to accept his application on account of his previous journalist work and exempted him from taking state exam for diplomatic-consular clerks. Radoje Janković was appointed General Consul in Chicago on $20^{\text {th }}$ May 1926. After he was transferred to post of General Consul in New York, in August 1929, he took with him personal confidential archive on Bulgarian propaganda. AY, 334-Personnel-157-480, 730 (1-4), 732-736, 740, 741; AY, 449-16-39 General Consul in New York Radoje Janković to the Executive Department of the Ministry of Foreign Affairs, Conf. No. 225 from $16^{\text {th }}$ December 1929; Military Archives, Inventory 17, Box 46, Folder 1, Record No. 1, Sheet 73; Ko je ko u Jugoslaviji, 54; Српски биографски речник, 303, 304. 
General Political Director Božidar Purić issued an order to the Yugoslav diplomatic representatives in the USA and Canada in February 1927, to monitor activities of the MPO, expecting propagandist work in connection to planned IMRO's guerrilla attacks from Bulgaria and Albania ${ }^{67}$ Nevertheless, the Legation in Washington and consulates reported problems with insufficient financial means for undertaking intelligence activity; they claimed that they could only rely on cooperation with emigrant groups loyal to Yugoslav state in February and March 1927. ${ }^{68}$ Božidar Purić dismissed objection that lack of finances can be an excuse for "ignorance and certain inactivity in this respect" on $16^{\text {th }}$ April 1927. At the same time, he requested the verification of information and account on possible exaggerations in report received from Ministry of Interior Affairs, on work of the IMRO supporters (македонствујушчих). The Ministry of Interior had informed the Ministry of Foreign Affairs on the success of Bulgarian-Macedonian propaganda in the USA. The MPO had modified its activity in order to be compatible with the social system and sentiments of the American public. Assemblies were organised as democratic political meetings where everyone, including antagonist individuals and groups, had the opportunity to ask questions and give a speech. Through discussions, concerts and cultural manifestations they established a connection with societies, clubs and politically important individuals focused on European problems and managed to exercise a certain influence over a group of American congressmen and senators interested particularly in the Macedonian question. The MPO formed amicable relations with charity trusts and humanitarian institutions while raising funds for refugees from Macedonia. Special attention was given to the American press, publishing articles on unfair peace treaties, and tyranny in socalled South Serbia and Aegean Macedonia. Ministry of Interior Affairs concluded that the MPO achieved great strength and their main task was to parry Serbian and Greek propaganda among Macedonian emigrants convincing them that the Macedonian question was not definitely solved. Proposed countermeasures were: 1. creating data base of all emigrants who had family members in South Serbia, so Yugoslav authorities could intervene through them; 2. appointing one clerk from South Serbia to each diplomatic-consular mission in North America in order to persuade ethnic Macedonians to be loyal to the Kingdom of SCS; 3. periodical visitations of "proven and intelligent" individuals from Macedonia to North America where they were to agitate for Yugoslavia. ${ }^{69}$ General Consul in Chicago Radoje Janković sent detailed reports concerning issues raised by the Ministry of Interior in March 1928 while the mission of the Konstantin Todorov was in progress.

In the beginning of August 1927, General Consul Đorđe Todorović reported that the MPO did not achieve any significant result after he had been

67 AY, 371-35-46, 121.

68 AY, 371-35-46, 122-124.

69 AY, 371-35-46, 125-139. 
appointed in January $1927 .^{70}$ General Consul Radoje Janković proposed to the Legation in Washington to use the services of Pavle Angelov, as he was financially secured, therefore reliable, and highly respected among emigrants from South Serbia as a former member of the Central Committee of the MPO. Pavle Angelov's estimation was that it was easy to annul the MPO's results, because members were spending a great deal of time and much effort in mutual strife, becoming wavering and did not believe in Bulgarian agitation. ${ }^{71}$ In November 1927, Ministry of Interior complained to the Ministry of Foreign Affairs on lose communication. They were gathering information from confidants in so-called South Serbia and Bulgaria on MPO's activities to raise money for the IMRO and did not receive a single report from the Legation or Consulates in North America on the precise results of the MPO activity. Also, the Ministry of Interior was referring to belated reports on returning of emigrants to South Serbia. ${ }^{72}$

\section{Bulgarian Exarchian Church and Serbian Orthodox Church}

In line with ongoing political campaigns, the Bulgarian and Serbian Church also accelerated their activities in North America. The Serbian Orthodox Church (SOC) could not have the same role in the USA as it had in Macedonia under Ottoman rule. Serbia, Bulgaria and Greece were using churches and schools to win the hearts and minds of the Macedonian population for their national causes before and during the wars 1912-1918. The Serbian eparchy was confronting new problem in the USA - naturalization. Nevertheless, members of the Bulgarian and Serbian church had taken active part in political and propaganda activities.

Two Bulgarian priests and former members of the IMRO David Nakov and Krsto Tsenov had an important political role in North America. Bulgarians had five churches in the USA and Canada: Steelton in Pennsylvania, Granit City in Illinois, Indianapolis in Indiana, Toledo in Ohio and Toronto ${ }^{73}$ in Canada. As a priest in Toronto, the largest Bulgarian-Macedonian colony in Canada, David Nakov was the leader of the local brotherhood and of the Bulgarian-Macedonian Committee. Krsto Tsenov had a distinguished role in reorganization of the Committee into the MPO. Therefore, the struggle of Yugoslav Foreign Service and the SOC against their activity had more political than religious aspects.

70 AY, 499-13-27 General Consulate in New York to the General Political Direction of the Ministry of Foreign Affairs and Legation in Washington, Conf. No. 91 from $3^{\text {rd }}$ August 1927.

71 AY, 371-35-46, 158-161.

72 AY, 499-13-27 Plenipotentiary Minister Vojislav Antonijević to the Royal Consulate in New York, Conf. No. 236/27 from $27^{\text {th }}$ January 1928.

73 According to Bulgarian sources largest Bulgarian colony in Canada was in Toronto numbering 1500 members in late 1923. According to the Yugoslav General Consul in Montreal Anto Seferović that colony had five to six thousand "Macedonians" consisting of 200 Bulgarians "by origin", rest were emigrants mostly from Aegean Macedonia and less from Vardar Macedonia in mid-1925 and early 1926. AY, 371-44-59, 455, 461; К. Гърдев, ор. cit., 54. 
After the First World War, Serbian Orthodox clergy in the USA had continued its emancipation from the jurisdiction of the Russian Orthodox Church which had begun in 1913. ${ }^{74}$ Diet of Serbian Orthodox priests was summoned in March 1919, it declared the Serbian Eparchy in the USA and Canada independent from the Russian Orthodox Church and Archimandrite Mardarije Uskoković was elected bishop. ${ }^{75}$ His ordination was delayed by the reorganization of the SOC and election of a new Serbian Patriarch. ${ }^{76}$ Holly Diet of the SOC had appointed Bishop of Žiča Nikolaj Velimirović administrator of American-Canadian eparchy and sent him to the USA to examine situation in Serbian parochial-school communions. He found a dissatisfying situation among priests who were working only for their personal gains. Therefore, Nikolaj Velimirović proposed to the Holly Diet of the SOC to ordain one bishop exclusively for the parishes in North America. ${ }^{77}$ Archimandrite Mardarije Uskoković was assigned as acting administrator of American-Canadian eparchy with permanent residence in the USA in December 1922 and he returned to North America at the beginning of 1923. Conference of Serbian priests summoned in Gary, $8^{\text {th }}-21^{\text {st }}$ February 1923, acknowledged his appointment, elected Episcopal Consistory and set their seat in Chicago. ${ }^{78}$ After the resignation of Nikolaj Velimirović from his post, Mardarije Uskoković was assigned as the new administrator in December $1923 .{ }^{79}$ Acting on the proposition of General Consul in New York Pavle Karović and request of the Episcopal Consistory from April-May $1924,{ }^{80}$ the Holly Diet of the SOC had

74 Др Ђоко Слијепчевић, Историја Српске Православне Цркве III. За време Другог светског рата и после њега, Београд, 2002, 207-209.

75 AY, 371-63-85, 2, 4, 12.

76 AY, 371-63-85, 49a, 58. On reorganization of the Serbian Orthodox Church: Радмила Радић, Држава и верске заједнище 1945-1970. Први део: 1945-1953, Београд, 2002, 19-21.

77 AY, 371-63-85, 29-31, 62, 90, 99, 100; B. Purić, Biografija Bože Rankovića, 158, 172-174; Ђ. Слијепчевић, ор. cit., 209; Mirko Dobrijević, “Bishop Nikolai Velimirovich's First Visit to America”, Serbian studies, Vol. 5, No. 2 (Fall 1989), 89, 90.

78 AY, 371-63-85, 108-110, 118; AY, 449-5-11 General Consul in Chicago Božidar Purić to the General Consul in New York Pavle Karović, Conf. No. 15 from $10^{\text {th }}$ January 1923, circular letter of Mardarije Uskoković to Orthodox bishops in America, Episcopal No. 10 from $10^{\text {th }}$ March 1923, Mardarije Uskoković to the General Consul in Chicago Božidar Purić, 14 ${ }^{\text {th }}$ March 1923; Archive of Yugoslavia, Records of the General Consulate of the Kingdom of Yugoslavia in Chicago, 414-3-6 (further: AY, 414) General Consul in Chicago Božidar Purić to the Plenipotentiary Minister in Washington Ante Tresić-Pavičić, Conf. No. 35 from 30 ${ }^{\text {th }}$ January 1923, circular letter of Mardarije Uskoković to the General Consul in Chicago Dr Božidar Purić, Episcopal No. 10 from $10^{\text {th }}$ March 1923, General Consul in Chicago Božidar Purić to the Minister of Foreign Affairs Momčilo Ninčić, Legation in Washington and consulates in America, Conf. No. 60 from $14^{\text {th }}$ March 1923, General Consul in Chicago Božidar Purić to the archimandrite Mardarije Uskoković, Conf. No. 64 from 14 ${ }^{\text {th }}$ Marsh 1923; B. Purić, Biografija Bože Rankovića, 174-177; Ђ. Слијепчевић, ор. cit., 209.

79 AY, 371-63-85, pp. 160-164; AY, 414-3-6 General Consul in Chicago Božidar Purić to the Political Department of the Ministry of Foreign Affairs, Ministry of Religious Affairs and Legation in Washington, Conf. No. 302 from 19 ${ }^{\text {th }}$ December 1923.

80 AY, 449-5-11 General Consul in New York Pavle Karović to the Minister of Foreign Affairs Momčilo Ninčić, Minister of Religious Affairs Vojislav Janić and Serbian Patriarch Dimitrije, Conf. No. 42 from 17 ${ }^{\text {th }}$ April 1924; Ђ. Слијепчевић, op. cit., 209. 
elected archimandrite Mardarije Uskoković for the American-Canadian bishop in December 1925 and ordained him on $25^{\text {th }}$ April $1926 .^{81}$

Observations made by Nikolaj Velimirović on the situation among Serbian clergy were confirmed by the Yugoslav diplomatic and consular representatives in the USA. According to their reports in more than 40 Orthodox communities there were 28 priests with various educational ${ }^{82}$ and moral merits. Their reputation and influence among parishioners was gradually declining after the First World War. ${ }^{83}$ Yugoslav diplomatic and consular representatives were advocating for a better organization of the Serbian Orthodox Eparchy in the USA and Canada as the best means for recovery of the church's and clergy's reputation among Serbian Diaspora. ${ }^{84}$ General Consuls in Chicago and New York were informing Legation and Ministry during 1919-1923 on different fractions among priests who were opposing the authority of the SOC, bishop Nikolaj Velimirović and archimandrite Mardarije Uskoković. ${ }^{85}$ Alongside with personal animosities, the struggle against authorities was caused by the will to remain independent or to retain their posts. ${ }^{86}$

General Consul in Chicago Božidar Purić and Plenipotentiary Minister in Washington Ante Tresić-Pavičić recognized the importance of archimandrite's work on behalf of Yugoslav interests in the USA in January-March 1923. They considered Mardarije Uskoković an appropriate person to suppress communist propaganda among Serbian Diaspora while his authority was derived from his position in the church hierarchy; adequate for struggle against Montenegrin separatist idea while he was born in Montenegro; and valuable for Yugoslav

81 AY, 371-63-85, pp. 178, 188; AY, 414-3-6 telegrams: General Consul in Chicago Božidar Purić to the General Consulate in New York, $10^{\text {th }}$ December 1925, Deputy Minister of Foreign Affairs Jovan Marković to the General Consulate in Chicago, Conf. No. 2459 from $10^{\text {th }}$ March 1926, Vice-Consul Naumović to the Rt. Rev. Mardarije, Chicago $10^{\text {th }}$ March 1926, Naumović to the Étrangères, Conf. No. 57 from $3^{\text {rd }}$ April 1926; Ђ. Слијепчевић, оp. cit., 209.

82 Only 8 of 28 priests were educated in Serbian or Russian theological schools, other 20 had different kinds of education.

83 AY, 414-3-6 and AY, 449-5-11 General Consul in Chicago Božidar Purić to the Minister of Foreign Affairs Momčilo Ninčić, Legation in Washington and Consulates in America, Conf. No. 60 from $14^{\text {th }}$ March 1923, General Consul in Chicago Božidar Purić to the Political Department of the Ministry of Foreign Affairs, Ministry of Religious Affairs and Legation in Washington, Conf. No. 302 from $19^{\text {th }}$ December 1923.

84 AY, 371-63-85, 4, 109, 110; AY, 414-3-6 General Consul in Chicago Božidar Purić to the Plenipotentiary Minister in Washington Ante Tresić-Pavičić, Conf. No. 35 from $30^{\text {th }}$ January 1923, General Consul in Chicago Božidar Purić to the Minister of Foreign Affairs Momčilo Ninčić, Legation in Washington and Consulates in America, Conf. No. 60 from $14^{\text {th }}$ March 1923; AY, 449-5-11 General Consul in New York Pavle Karović to the Minister of Foreign Affairs Momčilo Ninčić, Minister of Religious Affairs Vojislav Janić and Serbian Patriarch Dimitrije, Conf. No. 42 from $17^{\text {th }}$ April 1924.

85 AY, 371-63-85, 4, 99, 100, 163; AY, 414-3-6 General Consul in Chicago Božidar Purić to the Political Department of the Ministry of Foreign Affairs, Ministry of Religious Affairs and Legation in Washington, Conf. No. 302 from $19^{\text {th }}$ December 1923.

86 AY, 449-5-11 General Consul in New York Radoje Janković to the Serbian Patriarch Varnava, Conf. No. 68 from $19^{\text {th }}$ June 1930. 
propaganda among the American public while he had inherited connections within American Protestant circles from bishop Nikolaj Velimirović. ${ }^{87}$ Yugoslav Plenipotentiary Minister and General Consuls were helping Mardarije Uskoković to overcome opposition in the ranks of Serbian clergy during 1923 and in performing his duties from 1926 while he was suffering from tuberculosis. ${ }^{88}$ General Consul in Chicago Božidar Purić and Plenipotentiary Minister in Washington Ante Tresić-Pavičić advised the Ministry of Foreign Affairs to increase Mardarije Uskoković's monthly salary in order to support his authority. They highlighted ambivalence in expectations and reality. The SOC and Yugoslav Foreign Service were demanding from Mardarije Uskoković to act with authority among those circles from which he was depending on for financial support, i.e. Serbian clergy, Serbian Diaspora and American public. General Consul underlined that there was no more devastating impact on the reputation of the Kingdom of SCS in American public than "this beggarly propaganda which has been lingering since the war". After the Conference of Serbian priests in Gary had decided to collect 125 \$ monthly for Eparchy and administrator, Božidar Purić estimated that the Ministry of Foreign Affairs should award an additional $100 \$$ per month for the work of Mardarije Uskoković. ${ }^{89}$

The main task of the Serbian American-Canadian Eparchy was preserving national identity and prevention of naturalization among members the Serbian Diaspora particularly younger generations. ${ }^{90}$ Therefore, those Serbian priests

87 AY, 371-63-85, 111-113; AY, 414-3-6 General Consul in Chicago Božidar Purić to the Plenipotentiary Minister in Washington Ante Tresić-Pavičić, Conf. No. 35 from $30^{\text {th }}$ January 1923, General Consul in Chicago Božidar Purić to the Minister of Foreign Affairs Momčilo Ninčić, Legation in Washington and Consulates in America, Conf. No. 60 from $14^{\text {th }}$ March 1923; AY, 449-5-11 General Consul in Chicago Božidar Purić to the General Consul in New York Pavle Karović, Conf. No. 15 from $10^{\text {th }}$ January 1923.

88 AY, 414-3-6 General Consul in Chicago Božidar Purić to the Minister of Foreign Affairs Momčilo Ninčić, Legation in Washington and Consulates in America, Conf. No. 60 from $14^{\text {th }}$ March 1923, General Consul in Chicago Božidar Purić to the Plenipotentiary Minister Ante Tresić-Pavičić, Conf. No. 164 from $6^{\text {th }}$ June 1923, General Consul in Chicago Radoje Janković to the Minister of Foreign Affairs Vojislav Marinković and Legation in Washington, Conf. No. 9/28 from $2^{\text {nd }}$ January 1928, General Consul in Chicago Radoje Janković to the Legation in Washington, Conf. No. 32 from 19 $9^{\text {th }}$ April 1928, Conf. No. 50 from 24th May 1928, General Consul in Chicago Radoje Janković to the Minister of Foreign Affairs Vojislav Marinković, Conf. No. 50 from $24^{\text {th }}$ May 1928; AY, 449-5-11 General Consul in Chicago Božidar Purić to the Minister of Foreign Affairs Momčilo Ninčić, Legation in Washington and Consulates in America, Conf. No. 60 from $14^{\text {th }}$ March 1923, General Consul in New York Radoje Janković to the Serbian Patriarch Varnava, Conf. No. 68 from $19^{\text {th }}$ June 1930.

89 AY, 371-63-85, 111-117; AY, 414-3-6 General Consul in Chicago Božidar Purić to the Plenipotentiary Minister in Washington Ante Tresić-Pavičić, Conf. No. 35 from $30^{\text {th }}$ January 1923, Legation in Washington to the General Consulate in Chicago, P. No. 39 from $26^{\text {th }}$ February 1923, General Consul in Chicago Božidar Purić to the Minister of Foreign Affairs Momčilo Ninčić, Legation in Washington and Consulates in America, Conf. No. 60 from $14^{\text {th }}$ March 1923.

90 AY, 414-3-6 General Consul in Chicago Radoje Janković to the Minister of Foreign Affairs Vojislav Marinković and the Legation in Washington, Conf. No. 9 from $2^{\text {nd }}$ January 1930; AY, 449-16-37 General Consul in Chicago Božirad Purić to the Royal Legation in Washington and General Consulate in New York, Conf. No. 19 from $2^{\text {nd }}$ February 1925, General Consul in New York Pavle Karović to the Legation in Washington, Conf. No. 38 from $17^{\text {th }}$ February 1925. 
who were aware of their pastoral duties and were cooperating with Yugoslav diplomatic-consular missions were more dedicated to maintain Serbian parishes than to win over members of Bulgarian-Macedonian parishes. Illustrative is the report of priest Đorđe Petrović sent to the Department for Protection of the State of the Ministry of Interior Affairs in 1924. He had a parish in the MPO's stronghold in Steelton and less than 20 of 250 Serbian children knew the Serbian language. In order to attract children to learn the Serbian language and to use it in everyday life, he opened a Serbian school, evening singing lessons and amateur theater during working days, and family gatherings on Sunday evenings with lamb roast and non-alcoholic beer. Therefore, Dorđe Petrović had little time and opportunity for counterwork against the MPO and Bulgarian priest in Steelton. ${ }^{91}$

Yugoslav Ministry of Foreign Affairs was accustomed to the activity of priest David Nakov as the leader of the Bulgaro-Macedonian Committee in North America. Hence, Yugoslav Foreign Service immediately recognized Protosyngellos Dr Krsto Tsenov as a propaganda agitator sent by Bulgarian government to reorganize political activities of Macedonian Diaspora, although he was officially sent to the USA as a head of Bulgarian Church Mission in North America in August 1922. ${ }^{92}$ Their assumption was that Bulgarians had only five churches and therefore no need for a new priest. $^{93}$ Yet, Yugoslav Foreign Service did not have sufficient funds to track his work. ${ }^{94}$ After the reorganization of the Bulgarian-Macedonian Committee into the MPO, Božidar Purić concluded it was the result of the activity of Krsto Tsenov. Consequently, the Legation in Washington assigned consulates to follow his future work through cooperation with Yugoslav colonies. ${ }^{95}$

Before Yugoslav Foreign Service had started to conduct organized antiBulgarian and pro-Yugoslav propaganda through cooperation with Mardarije Uskoković in 1923, there were individual attempts by Serbian priests to follow and counteract activities of the BEC. The most devoted was Danilo Kozomara in one the largest Bulgarian-Macedonian colonies in the USA in Steelton. He informed Legation in Washington in 1919-1920 that Macedonian parishioners had separated from the Serbs and founded a new Church. Under leadership of Bulgarian priest and former komitadji they were working on raising so-called Macedonian question. ${ }^{96}$

91 AY, 449-5-11 Ministry of Foreign Affairs to the General Consulate in New York, Conf. No. 942 $20^{\text {th }}$ February 1925.

92 AY, 449-13-27 Plenipotentiary Minister in Washington Slavko Grujić to the General Consul in New York Pavle Karović, Conf. No. 408 from 24 $4^{\text {th }}$ August 1922.

93 Б. Пурић, Наши исељеници, 52.

94 AY, 449-13-27 General Consul in New York Pavle Karović to the Legation in Washington, Conf. No. 33 from $8^{\text {th }}$ September 1922, General Consul in New York Pavle Karović to the Legation in Washington, Ref. Conf. No. 33 from $9^{\text {th }}$ September 1922, General Consul in Chicago Božidar Purić to the Ante Tresić-Pavičić and General Consulate in New York, Conf. No. 119 from $2^{\text {nd }}$ October 1922.

95 AY, 371-34-45, 293, 294; AY, 449-13-27 General Consul in Chicago Božidar Purić to the Plenipotentiary Minister Ante Tresić-Pavičić and General Consulate in New York, Conf. No. 145 from $26^{\text {th }}$ October 1922, Plenipotentiary Minister Ante Tresić-Pavičić to the General Consulate in New York, Conf. No. 518 from 31 $1^{\text {st }}$ October 1922. 
According to the preserved records, cooperation of the Serbian American-Canadian Eparchy with Yugoslav Foreign Service against the BEC in North America began in the last quarter of $1923 .{ }^{97}$ Simultaneously with declining enthusiasm of the MPO the Bulgarian Church lost in November 1923 the priest in Indianapolis Velko Popov whose parish also covered state Indiana and Headquarters of the MPO in Fort Wayne. The Serbian Orthodox Church had assigned David Popović as priest in Kansas City, Missouri in October 1923. On the recommendations of General Consuls in New York and Chicago Pavle Karović and Božidar Purić, Mardarije Uskoković reassigned him as a priest in South Bend, Indiana. His election was not random, because he was known to Macedonian emigrants, through Bulgarian press, as former school teacher who often intervened with Serbian military authorities in favor of local residents, after the liberation of South Serbia in 1918. This was an opportunity to implement the forth point of Božidar Purić's plan and win over all members of the MPO who had started to doubt in their hitherto work. General Consul in Chicago asked archimandrite Mardarije Uskoković to expand his parish from South Bend to entire state Indiana in November 1923. Božidar Purić had sent to David Popović detailed information on existing Bulgarian propaganda and instructions to organize parochial-school community in cooperation with Yugoslav Diaspora and start counteraction against Bulgarian-Macedonian organisations. ${ }^{98}$ During the next years David Popović was distinguished member of Serbian Eparchy due to his work for national and state interests. ${ }^{99}$ Mardarije Uskoković tried to move him to the Chicago so he could counter pro-Bulgarian actions in state Illinois. But David Popović lost the elections after the parishioners had found out that he was the candidate of Serbian American-Canadian Eparchy. ${ }^{100}$

Yugoslav diplomatic-consular missions in North America were stimulated toward closer cooperation with the Serbian American-Canadian Eparchy due to strengthening of anti-state propagandas and differences among loyalty of Serbian and Croatian clergy toward the Kingdom of SCS. During December 1923 - August 1924, Yugoslav Foreign Service was particularly interested in collaboration with the Serbian Eparchy in order to improve the reputation of the Kingdom of SCS in Yugoslav Diaspora and American public and against Bulgarian propaganda aimed toward guerilla operations in so-called South Serbia. Main disadvantages were insufficient funds of Yugoslav Foreign

97 Recall of David Nakov from post in Toronto, in April 1923, was result of the action taken by General Consulate in Montreal and the SND and there is no information that Serbian AmericanCanadian Eparchy had any role in this action.

98 AY, 371-34-45, 328; AY, 414-3-6 and AY, 449-5-11 General Consul in New York Dr Pavle Karović to the general in Chicago Božidar Purić, Conf. No. 145 from 17 th October 1923; AY, 449-13-27 General Consul in Chicago Božidar Purić to the Royal Legation in Washington and General Consulate in New York, Conf. No. 266 from $20^{\text {th }}$ November 1923.

99 AY, 449-5-11 General Consul in New York Radoje Janković to the Plenipotentiary Minister in Washington Leonid Pitamec, Conf. No. 221 from $9^{\text {th }}$ December 1929.

100 AY, 414-3-6 priest David Popović to the Božidar Purić, Omaha $28^{\text {th }}$ January 1926. 
Service, loose communication between diplomatic-consular missions and Serbian clergy, non-existing allegiance of Croatian priests to the state created by Serbs. ${ }^{101}$ The weakest point in this plan was Canada where the BEC had sent several priests after the First World War and the SOC had not assigned any priest to the only church it had in Hamilton, Ontario. Hamilton church was only occasionally visited by the Serbian priests who were traveling through Canada. ${ }^{102}$

Disadvantage of the SOC in Canada was exceeded by the recall of the priest in Toronto David Nakov, who had taken new post in Steelton continuing pro-Bulgarian propaganda among Macedonian parishioners. Serbian priest in Steelton Đorđe Petrović was unable to counter his work during 1924-1925 while his main focus was on preserving national identity among 40-50 Serbian families. ${ }^{103}$ While Đorđe Petrović had support of Protosyngellos Danilo Kozomara, he had loose communication with General Consulate in New York. Đorđe Petorvić had sent to the General Consulate in New York list of Macedonians who were working for Bulgarian propaganda and were parishioners of Bulgarian Exarchial Church, and proposed to the General Consulate to send circular letter to the Macedonians with an explanation of the consequences if they remained loyal to the Bulgarian Church. General Consul Pavle Karović had recommended to the Legation in Washington and archimandrite Mardarije Uskoković his propositions, but did not take active role. ${ }^{104}$

101 AY, 371-35-45, 609-611; AY, 371-63-85, 164, 165; AY, 414-3-6 General Consul Božidar Purić to the Political Department of the Ministry of Foreign Affairs, Ministry of Religious Affairs and Legation in Washington, Conf. No. 302 from 19 ${ }^{\text {th }}$ December 1923; AY, 449-13-27 Plenipotentiary Minister Ante Tresić-Pavičić to the general consul in New York Pavle Karović, Conf. No. 492 from $16^{\text {th }}$ August 1924.

102 General Consul in Montreal Anto Seferović was able to support supposedly assigned Serbian priest with 50 \$ per month until he would win over most of the Macedonian parishioners, yet this question was not resolved in 1925. AY, 371-44-59, 440-443, 459.

103 AY, 449-5-11 Ministry of Foreign Affairs to the General Consulate in New York, Conf. No. 942 $20^{\text {th }}$ February 1925.

104 For instance, in the case of Milan Talević (Milan Talev-Pajmak) the General Consul in New York had more confidence in the words of the Macedonian emigrant than in the report received by Protosyngellos Danilo Kozomara. AY, 449-13-27 priest Đorđe A. Petrović to the General Consulate of the Kingdom of Serbs, Croats and Slovenes, Steelton from $2^{\text {nd }}$ September 1924, General Consul in New York Pavle Karović to the Legation of the Kingdom of the Serbs, Croats and Slovenes in Washington and Archimandrite Mardarije, $12^{\text {th }}$ August 1924, General Consul in New York Pavle Karović to the Ministry of Foreign Affairs and priest Đorđe A. Petrović, Conf. No. 81 from $12^{\text {th }}$ August 1924, priest Đorđe A. Petrović to the General Consulate in New York, Steelton $2^{\text {nd }}$ September 1924, General Consul Pavle Karović to the Legation in Washington, connection Conf. No. 89 from $5^{\text {th }}$ September 1924, Protosyngellos Danilo Kozomara to the General Consulate in New York, Steelton $18^{\text {th }}$ November 1925, protosyngellos Danilo Kozomara to the General Consul in New York Pavle Karović, Steelton 21 ${ }^{\text {st }}$ December 1925, General Consul Pavle Karović to the Danilo Kozomara, New York 23 $3^{\text {rd }}$ December 1925, General Consul Pavle Karović to the Political Department of the Ministry of Foreign Affairs, Conf. No. 133 from $23^{\text {rd }}$ December 1925, General Consul in New York Pavle Karović to the Political Department of Ministry of Foreign Affairs, Conf. No. [illegible] from $30^{\text {th }}$ December 1925, general consul in New York Đorđe Todorović to the protosyngellos Danilo Kozomara, Conf. No. 7 from $11^{\text {th }}$ January 1926, Protosyngellos Danilo Kozomara to the General Consul Đorđe Todorović, Steelton $13^{\text {th }}$ January 1926; AY, 449-5-11 Ministry of Foreign Affairs to the General Consulate in New York, Conf. No. 942 from $20^{\text {th }}$ February 1925. 
Serbian priests frequently proposed to the Yugoslav consular missions to decline any application for a Yugoslav passport and visas to persons who could not obtain a certificate from Serbian priests that they were acting loyal to the Kingdom of SCS while they were living in the USA or Canada. ${ }^{105}$

Analyzing their experiences in collaboration with the SOC in struggle against Bulgarian propaganda during 1924-1925, General Consuls in New York and Chicago could report a different state of the affairs. Pavle Karović concluded there were several reasons why Serbian priests had not achieved significant results among Macedonian parishioners. On one hand, the BEC had sent number of Bulgarian priests to the USA with more than sufficient funds for their work among the Macedonian Diaspora. On the other hand, the Ministry of Foreign Affairs and the SOC sent Serbian clergy expecting they could win over Macedonians only with "kind word" and "potential" recognition of their service by the Yugoslav state. Pavle Karović concluded that Serbian priests could do little while members of Macedonian Diaspora were threatened by IMRO's retaliation against their families in South Serbia and that the SOC should send at least ten "decent" priests to support the work of Archimandrite Mardarije Uskoković, with 50 \$ monthly allowance (500 \$ monthly in total) and detailed instructions on counteraction against Bulgarian-Macedonian propaganda. ${ }^{106}$ Božidar Purić estimated that the General Consulate in Chicago achieved good results in cooperation with Serbian clergy on the territory under their jurisdiction. ${ }^{107}$

Efforts of Mardarije Uskoković in service of Yugoslav diplomacy and propaganda were appreciated by the Ministry of Foreign Affairs. After he had been ordained bishop of American-Canadian Eparchy, in April 1926, Minister of Foreign Affairs decided to grant him a subsidy of 500 \$ monthly from classified funds. Nevertheless, General Consul in Chicago Radoje Janković proposed to the Ministry of Foreign Affairs, during first half of 1928, to replace Mardarije Uskoković because he was not able to take an active role in the life of Diaspora

105 AY, 449-13-27 Syngellos and Vice-President of the "Srbobran" Daniel Kozomara to the Royal General Consulate of the Kingdom of SCS in New York, Steelton 27 ${ }^{\text {th }}$ September 1920, General Consulate in New York to Syngellos Daniel Kozomara, Ref. Conf. No. 55 from $5^{\text {th }}$ October 1920, Syngellos Daniel Kozomara to the General Consulate in New York, $7^{\text {th }}$ October 1920, priest Đorđe A. Petrović to the General Consulate of the Kingdom of Serbs, Croats and Slovenes, Steelton from $2^{\text {nd }}$ September 1924, General Consul in New York Pavle Karović to the Legation of the Kingdom of the Serbs, Croats and Slovenes in Washington and archimandrite Mardarije, $12^{\text {th }}$ August 1924, General Consul in New York Pavle Karović to the Ministry of Foreign Affairs and priest Đorđe A. Petrović, Conf. No. 81 from $12^{\text {th }}$ August 1924, priest Đorđe A. Petrović to the General Consulate in New York, Steelton $2^{\text {nd }}$ September 1924, General Consul Pavle Karović to the Legation in Washington, connection Conf. No. 89 from $5^{\text {th }}$ September 1924, priest David Popović to the General Consul in New York Đorđe Todorović, Lackawanna from $22^{\text {nd }}$ December 1927, priest Daniel Kozomara to the General Consul in New York, $12^{\text {th }}$ January 1928; AY, 449-5-11 Ministry of Foreign Affairs to the General Consulate in New York, Conf. No. 942 from $20^{\text {th }}$ February 1925.

106 AY, 449-16-37 General Consul in New York Pavle Karović to the Legation in Washington, Conf. No. 38 from $17^{\text {th }}$ February 1925.

107 AY, 449-16-37 General Consul in Chicago Božidar Purić to the Royal Legation in Washington and General Consulate in New York, Conf. No. 19 from $2^{\text {nd }}$ February 1925. 
or Yugoslav propaganda due to his serious illness. ${ }^{108}$ During 1929-1934, Serbian priests David Popović and Marko Komnenić in cooperation with General Consuls in New York Đorđe Todorović and Radoje Janković managed to alienate Bulgarian priests David Nakov and Krsto Tsenov, while they had supported the prior during his trial with the later in Magistrate of Harrisburg so he could create new Macedonian Church in Steelton independent from Bulgarian Exarchial Church. ${ }^{109}$

\section{The Mission of the Konstantin Todorov}

Ministry of Foreign Affairs undertook an extended action against Bulgarian-Macedonian organisations in the second half of 1927. Aim was to win over simultaneously the Macedonian Diaspora and American public for Yugoslav thesis. First phase was initiated by bishop Nikolaj Velimirovićs lectures delivered in American churches, during August-October that year. He was officially invited by American-Yugoslav Society in New York, with aim to avoid any connection with official diplomacy. Bishop Velimirović was trying to explain the general practice of compulsory closures of Bulgarian-language schools and current state of religious life in South Serbia by contrasting them with striking accounts of contemporary IMRO's terrorist actions and former Ottoman rules in Macedonia, both of which were discarded for their anti-Christian nature and character. By criticising bishop`s lectures, the new Chief of Macedonian Press Bureau in New York Hristo Nazimov tried to advocate IMRO's activities which were taking place primarily as consequence of harsh prosecutions imposed by regimes in both Yugoslav and Greek parts of Macedonia. ${ }^{110}$

Konstantin Todorov arrived in the USA after Nikolaj Velimirović's departure. He spent seven months in North America, from November 1927 to May 1928, but dedicated only one page in his memoirs to this episode. Since it was published in New York during 1943, he probably could not reveal his activities in Yugoslav service on American soil in interwar period, while he was affiliated with the Yugoslav government throughout the Second World War. He devoted more space in his memoirs to the meeting with the notorious gangster Joe Morgan, opponent of Alphonso "Al" Capone in Chicago than to his mission. ${ }^{111}$

108 From preserved records it is not clear when exactly did Ministry make this decision; author of this article could only conclude it was during period 1926-1928. AY, 414-3-6 General Consul in Chicago Radoje Janković to the Legation in Washington, Conf. No. 32 from $19^{\text {th }}$ April 1928, General Consul in Chicago Radoje Janković to the Minister of Foreign Affairs Vojislav Marinković, Conf. No. 50 from 24 ${ }^{\text {th }}$ May 1928.

109 AY, 449-13-27 letters of General Consul Đorđe Todorović to the priest Marko Komnenić, New York from $20^{\text {th }}$ May and $25^{\text {th }}$ June 1929 , letters of priest Marko Komnenić to the General Consul Đorđe Todorović, Steelton from $28^{\text {th }}$ May and $1^{\text {st }}$ July 1929, General Consul Đorđe Todorović to the General Political Direction of the Ministry of Foreign Affairs, Conf. No. 161 from $10^{\text {th }}$ June 1929; AY, 371-36-47, 284-295.

110 AY, 371-35-46, 148-156; AY, 371-63-85, 201-203, 205, 206, 227, 228.

111 Kosta Todorov, Balkan Firebrand, New York, 1943, 227, 228; Bulgarian edition: Коста Василев Тодоров, Изповедта на една луда балканската глава, София, 1994, 316, 317. 
Before he had left Europe, Konstantin Todorov circulated his publication - La vérité sur l'Organisation Révolutionaire Intérieure Macédonienne, printed in Paris in 1927 - to Yugoslav representatives in North America, editorial boards of American press and individuals concerned with the Macedonian question. ${ }^{112}$ His stay was planned with Minister of Foreign Affairs Vojislav Marinković, ${ }^{113}$ and coincided with the signing of Yugoslav-French and Italo-Albanian agreements. ${ }^{114}$ In his memoirs, Konstanin Todorov stated that he had been traveling with a French passport received personally from General Secretary for Foreign Affairs Philippe Berthelot. ${ }^{115}$ At the same time, Yugoslav Ministry of Foreign Affairs did not officially inform either Yugoslav Legation in Washington or General Consulates in New York and Chicago of his arrival. ${ }^{116}$ Konstantin Todorov asked General Consul in New York Đorđe Todorović for instructions on $16^{\text {th }}$ November 1927. His first step was to attend to State Secretary Frank Billings Kellogg and other American statesmen connected with MPO's leader Lambo Kiselinchev. ${ }^{117}$ Konstantin Todorov received support from American-Yugoslav Society in New York and his stay aroused first rumours of assassination planned by the IMRO. ${ }^{118}$ In December 1927, Ministry of Foreign Affairs approved to the General Consulate in Chicago particular credit scheme for propaganda toward Yugoslav emigrants via American press; it permitted use of reliable individuals, and accepted Unification of South Slavs as anti-thesis to the MPO's ideas, ordering Yugoslav representatives to pay special attention to the American public. ${ }^{119}$

Alongside Yugoslav Foreign Service and American-Yugoslav Society in New York, Konstantin Todorov had support from Czechoslovakian Diaspora,

112 AY, 449-13-27 General Consulate in Genève to the General Consulate in New York, Conf. No. 87 from $24^{\text {th }}$ September 1927.

113 AY, 449-13-27 General Consul in New York Đorđe Todorović to the Plenipotentiary Minister in Washington Vojislav Antonijević, Conf. No. 23 from 25 th January 1928.

114 For further readings on these treaties: Vuk Vinaver, Jugoslavija i Francuska između dva rata. Da li je Jugoslavija bila francuski „satelit“, Beograd 1985, 116-127; Stanislav Sretenović, Francuska i Kraljevina Srba, Hrvata i Slovenaca 1918-1929, Beograd, 2008, 323-327; Саша Мишић, Албанија: пријатељ и противник. Југословенска политика према Албанији 19241927, Београд, 2009, 158-161.

115 К. В. Тодоров, ор. cit., 316.

116 AY, 414-8-17 and AY, 449-13-27 General Consul in New York Đorđe Todorović to the General Consul in Chicago, Conf. No. 29 from $8^{\text {th }}$ February 1928.

117 Lambo Kiselinchev was a member of the Central Committee of the MPO and one of two directors of the Macedonian Press Bureau in New York. His father was a millionaire with close connections with the Central Committee of the IMRO in Sofia. AY, 371-35-46, 91, 772-778.

118 AY, 371-35-46, 171-180; AY, 449-13-27 Plenipotentiary Minister in Washington Vojislav Antonijević to the General Consul in New York Đorđe Todorović, Conf. No. 10, Conf. No. 11 and Conf. No. 13 from $8^{\text {th }}$ and $21^{\text {st }}$ January 1928.

119 AY, 414-8-17 and AY, 449-13-27 Chief of III section of the Political Department of the Ministry of Foreign Affairs to the Royal General Consulate in Chicago, Conf. No. 6977 from $11^{\text {th }}$ June 1928; AY, 449-13-27 General Consul in New York Đorđe Todorović to the General Political Direction of the Ministry of Foreign Affairs, Conf. No. 117 from $16^{\text {th }}$ June 1928, General Political Director Stevan K. Pavlović to the General Consulate in New York, Conf. No. 10101 from 25 $5^{\text {th }}$ August 1928; AY, 371-35-46, 279-281. 
represented in American public as neutral side in the South Slav discussions. Opposition and hostile groups were invited to attend his lectures and they were allowed to debate with the speaker. In addition to expected opposition of Macedonian-Bulgarian and Croatian emigrants, communists took an active role in these debates as well. Konstantin Todorov based his arguments on increasing number of supporters for the idea of Yugoslav-Bulgarian rapprochement in both kingdoms and avoided to discuss the dynasty question. ${ }^{120}$

After spending two months in New York, he travelled to Canada where he cooperated with General Consulate in Montreal. In January 1928, ${ }^{121}$ he spent one or two weeks there and returned to the USA. The most significant part of his mission took place on the territory under jurisdiction of General Consulate in Chicago, where the MPO's main strongholds were located. At the beginning of his work in Chicago in February 1928, Konstantin Todorov proposed to the General Consul Radoje Janković that logistic should be designated to one discretely organised committee. In order to cover material costs of organising movement for Yugoslav-Bulgarian alliance, his advice was that tickets for lectures should not be cheaper than 75 cents or $1 \$$. His plan was to stay one week in Chicago and then to visit all places with South Slav colonies under jurisdiction of the General Consulate. ${ }^{122}$ Radoje Janković had estimated that tickets price should be $50 \$$ and he took care of the promotion. ${ }^{123}$

Committee for support was organised by "Srbobran", ${ }^{124}$ publishing articles and announcements for lectures and explaining discussion topics. Preparing the ground for speech in MPO's stronghold Gary, scheduled for $19^{\text {th }}$ February 1928, Konstantin Todorov was represented as a democrat, which could suited the American public and could attract attention of larger number of Macedonians and Bulgarians. Namely, he was referred to as a former Bulgarian delegate in the League of Nations and as advocate of Bulgarian-Yugoslav Union; and in an article written for the American press, the name of the Bulgarian Agrarian National Union was translated into English as "Democratic Party". Suggestion of Radoje Janković was accepted and ticket price was $50 \$ .{ }^{125}$ Lecture was held under presidency of a certain ethnic "Bulgarian" Dr Stoykov in a

120 AY, 371-35-46, 188-191.

121 AY, 449-13-27 General Consul in New York Đorđe Todorović to the Plenipotentiary Minister in Washington Vojislav Antonijević, Conf. No. 23 from $25^{\text {th }}$ January 1928.

122 AY, 414-8-17 Kosta Todorov to the General Consul in Chicago Radoje Janković, $6^{\text {th }}$ February 1928.

123 AY, 414-8-17 General Consul Radoje Janković to Kosta Todorov, 8 $8^{\text {th }}$ February 1928.

124 "Srbobran" was one of two major organizations of Serbian Diaspora in the USA before the First World War and during interwar period. They supported foreign and domestic policies of the Yugoslav governments in their newspaper American Srbobran, published in Pittsburgh, from the First World War until 25 $5^{\text {th }}$ March 1941. B. Purić, Biografija Bože Rankovića, 154, 155, 182, 183; I. Čizmić, op. cit., 105-115; U. Ostojić-Fejić, op. cit., 129, 135; A. N. Dragnich, op. cit., 13-16.

125 AY, 414-8-17 clippings „Г. Коста Тодоров“, Србобран from 14 ${ }^{\text {th }}$ February 1928; undated and unsigned text of an article sent to American press; Political Conference on Sunday, February 19, 1928, at Serbian Dom 14th and Madison sts., Gary, Ind. 
Serbian home, and it was attended by significant number of Macedonians and Bulgarians. ${ }^{126}$

Successful action in Gary was the rehearsal for the key step. Up until then, Konstantin Todorov was giving series of lectures, and in Chicago he had started organising Yugoslav-Bulgarian Society with task of gradual detachment of Macedonians from the MPO. Committee for support represented him through Chicago Daily News ${ }^{127}$ as prominent democrat known to be well aquatinted with the political and economic situation on the Balkans. ${ }^{128}$ "Srbobran" suggested that he should adjust lecture to Macedonian's attitudes, because emigrants from South Serbia were equally fed up with Serbian/Yugoslav as with Bulgarian propaganda. Therefore, "Srbobran" estimated that the Macedonians would like Konstantin Todorov to introduce them to the ideas of an independent or autonomous Macedonia, as core of "the U.S. of the Balkans". ${ }^{129}$ Czechoslovakian colony in Chicago was working on expanding the idea of South Slav's Unity to all-Slav's solidarity, as a counterbalance to Italian intentions. Therefore, the lecture was advertised by Hrvatski glasnik, and not in Serbian papers, and was organised in the Bohemian-American Hall. Invitation was sent to "Bulgarians, Russians, Yugoslavs together with Macedonians, Czechs and Pols" to attend "AllSlavs assembly" and it was underlined that he would speak on relations between Italy, Kingdom of SCS and Bulgaria. ${ }^{130}$

In the interview for Chicago Daily News, Konstantin Todorov elaborated the thesis on unification of South Slavs in a wider European context. By criticising Bulgarian foreign policy which was based on the support of Rome and London, he highlighted that France, Czechoslovakia, British Labour Party and German Minister of Foreign Affairs Gustav Stresemann were supporting Yugoslav resistance to Italian penetration in the Balkans. Those who opposed Yugoslavia were to be found in Italian fascists, Soviet bolshevists and reactionary regimes in Europe. ${ }^{131}$ The aforementioned Committee for Support had published "Appeal to all South Slavs in the United States and Canada" in order to win over South Slav emigration. Italian threat to the Balkan Peninsula was anticipated through the status of Slovenian and Croatian minorities in Italy; while political-cultural ideas and struggles of Serbs, Montenegrins, Bulgarians, Croats and Slovenians in $19^{\text {th }}$ and $20^{\text {th }}$ century were levelled on the same plain. Resistance against Italy was highlighted as a main task of future mutual work of all South Slavs.

126 AY, 414-8-17 clipping „Др Коста Тодоров у Чикагу“, Srpski dnevnik.

127 In 1924, Ante Tresić-Pavičić and Božidar Purić recognized the Chicago press as the most hostile toward the Kingdom of SCS. AY, 371-75-98, 96-97b, 112-115.

128 AY, 414-8-17 John Warandos to Mr. Charles H. Dennis, Managing Editor Chicago Daily News, Chicago, Ill., February 23, 1928.

129 AY, 414-8-17 President of the Srbobran-Sloga in Pittsburgh Dušan D. Silaški to the General Consul in Chicago Radoje Janković, 3/29

130 AY, 414-8-17 clipping „Poziv“, Hrvatski glasnik from 23 ${ }^{\text {th }}$ February 1928.

131 AY, 414-8-17 clipping "Bulgarian Hopes for Slavic Union: Dr. Kosta Todorov Voices Ambition to See Peace in the Balkans", Chicago Daily News from 25 $5^{\text {th }}$ February 1928. 
In that context, the IMRO and all their branches (implicated the MPO) were designated as servants of Italian imperialism motivated by selfish financial profits. Therefore "Appeal" demanded from emigrants to cease financial and moral support to Macedonian organisations and to start backing the movement for Yugoslav-Bulgarian unification. ${ }^{132}$ Before his lecture, Konstantin Todorov had asked Radoje Janković to help establish Society of all Yugoslavs in the Balkans. ${ }^{133}$

Assembly was attended by 300 persons, under presidency of a certain ethnic Croat Mamek, on $26^{\text {th }}$ February 1928. In order to introduce the audience to the Italian threat common to all South Slavs Konstantin Todorov pointed out the consequences of the signed treaty between Italy and Albania. He emphasized the project of the political union of the Kingdom of SCS and the Third Bulgarian Empire as a first step in unification of all Slavs in one state with 300 million inhabitants (ethnic Russians included). On the conference, Croats and Czechoslovakians appealed for South Slav's solidarity. Resolution of former member of Yugoslav National Council in the USA Dr Ante Biankini was passed on forming a Permanent Committee for Bulgarian-Yugoslav Unification with headquarters in Chicago. ${ }^{134}$ General Consul Radoje Janković had estimated that it was necessary to obtain 800 \$ monthly for successful work of the committee, but General Consulate in Chicago could dispose only 50 \$ from confidential credit. ${ }^{135}$ Ministry of Foreign Affairs was pleased with results and allowed additional 500 $\$$ credit for establishing Bulgarian-Yugoslav branches in North America. ${ }^{136}$

Nevertheless, General Consulate in Chicago and Legation in Washington reiterated their requests for additional financial support. General Consul Radoje Janković sent two detailed elaborates regarding Macedonian emigration, on $3^{\text {rd }}$ and $9^{\text {th }}$ March 1928, making proposals for future efforts:

1. Winning over trustworthy Macedonians for Yugoslav intelligence to gather information on exact number of MPO's members and exact financial strength of that organisation; detecting communication lines between Central Committee and local brotherhoods, and between the MPO and the IMRO;

132 AY, 414-8-17 announcement Сазивачи, „Апел свим Јужним Словенима у Сједињеним Државама и Канади“.

133 AY, 371-35-46, 201, 209.

134 AY, 414-8-17 clippings "World Expects Yearly Balkan War, Envoy Says”, Chicago Tribune from $27^{\text {th }}$ February 1928; „Др Коста Тодоров у Чикагу“, Srpski dnevnik; Ристо М. Томашевић, „Др. Коста Тодоров у Чикагу“, Српски дневник from $28^{\text {th }}$ February 1928.

135 AY, 449-16-39 General Consul in New York Radoje Janković to the Executive Department of the Ministry of Foreign Affairs, Conf. No. 225 from $16^{\text {th }}$ December 1929.

136 AY, 371-35-46, 231, 299, 300; AY, 449-13-27 Kosta Todorov to the General Consule in New York Đorđe Todorović, Akron 27 $7^{\text {th }}$ March 1928; AY, 414-8-17 Kosta Todorov to the General Consul in Chicago Radoje Janković, Mihaljevic Bros. Steamship Agency, Cleveland; Kosta Todorov to the General Consulate in Chicago Radoje Janković, Detroit $7^{\text {th }}$ April 1928; General Consul in Chicago Radoje Janković to the Department of Audit of Ministry of Foreign Affairs, Conf. No. 57 from $2^{\text {nd }}$ June 1928. 
2. Centralisation of Yugoslav intelligence service and total discretion of its work, avoiding exposure of their sources, referring to incidents with publication of official reports in Belgrade press and indiscretions of authorities in South Serbia;

3. Paying more attention to threats of the IMRO to Yugoslav confidants, who were well paid but living in fear;

4. Sending documents to the Department for State Security of the Ministry of Internal Affairs in sealed envelopes and reporting only general information to the Ministry of Foreign Affairs;

5. Centralisation of confidential funds, referring that Macedonians accept only strictly confidential, oral communication, without written reports or signing receipts for money.

Radoje Janković defined as the main goal of Yugoslav diplomatic-consular service to gather exact and reliable evidences of Bulgarian activities in North America as preparation for an official request for intervention of the American government against subversive anti-Yugoslav activity of Macedonian Diaspora. Comparing the Yugoslav experience in the USA with the Serbian one in the Ottoman Empire, General Consul underlined that in both cases the Bulgarians first started propaganda activities, yet their lack of discipline was breaking their ranks. Therefore, Radoje Janković saw the discipline of the Yugoslav Foreign Service as an advantage. Replying to the request of General Political Director Božidar Purić, from $16^{\text {th }}$ April 1927, Radoje Janković concluded that the Ministry of Interior Affairs possessed incorrect and exaggerated information on the MPO. Radoje Janković proposed that police authorities in South Serbia should put more pressure on the emigrants' families as he thought that Macedonians could only appreciate "strong-arm" policy until they realised that Kingdom of SCS was not a transient state. He thought that the MPO achieved greatest success in the American press, contrary to their activities in emigration community which proved to be failure. Radoje Janković warned the Ministry of Foreign Affairs that American authorities were deporting persons to the countries of their origin, sending emigrants from South Serbia to Bulgaria if they declared themselves as Bulgarians, thus avoiding punishment for their crimes against the Kingdom of SCS.

Legation in Washington informed Ministry of Foreign Affairs that the only reason why Macedonian emigrants were not actively propagating the idea of independent Macedonia was due to international circumstances. Unlike General Consul Radoje Janković, Chargé d'Affaires Branko Adžemović, ${ }^{137}$ who

137 Branko Adžemović was born in Trstenik in 1888; graduated from the Faculty of Law in Belgrade; he had a good knowledge of the English language; served in the Serbian Army 19141919; worked as a court clerk and judge in Aranđelovac in 1919; worked in the Ministry of Foreign Affairs since 1920. He was appointed Vice-Consul in New York 1920; he worked in the Ministry 1921-1923; he was acting Consul in Denver 1923, and since 1924 he worked in the Legation in Washington. AY, 334-Personnel-136-459, 344 (1-4), 348, 351, 360, 361, 366-368, $378,379,389,390,403-406$. 
had been assigned to monitor Yugoslav Diaspora, thought it was not wise to spend money on publishing articles in American press. ${ }^{138}$ His conclusion was that congressmen and senators were interested in Bulgarian propaganda slogans just because they were personal friends with Simeon Radev. Branko Adžemović proposed that focused attention on the American correspondents had greater influence, and they were just transiting Yugoslav territory while they were staying in Bulgaria. ${ }^{139}$

Yugoslav colony in Canada under leadership of Božidar Marković and in cooperation with former archimandrite and then pharmacist Dr Dimitry Malinov $^{140}$ (who was predecessor of David Nakov as priest in Toronto and predecessor of Krsto Tsenov as the Head of Bulgarian Church Mission in North America) invited Konstatin Todorov to give a lecture in MPO's stronghold in Toronto, because strife between autonomists and communists had caused anxiety and doubts amid Bulgarian-Macedonian colony. ${ }^{141}$

Success of the mission provoked a reaction of the MPO and Bulgarian Foreign Service. Jordan Chkartov planned to travel to Canada and struggle against communists. ${ }^{142}$ Stoyan Omrachevski ${ }^{143}$ arrived in New York in March

138 Polemics among Yugoslav diplomatic-consular representatives in the USA on question of effectiveness of publishing articles in American press was on going during the whole observed period 1919-1928. Numbers of reports with various standpoints are preserved in Records of the Legation in Washington and General Consulates in New York and Chicago.

139 AY, 371-35-46, 196-228.

140 Dimitry Malinov (Dimitry Georgiev Malinchev) was born in Bulgaria in 1882; he took part in Ilinden's uprising in 1903; emigrated to North America in 1907 as Orthodox priest; he was Archimandrite of Macedonian-Bulgarian church in Toronto 1910-1920. After the outbreak of the First World War he gave lectures on the situation on European fronts to the Macedonian, Bulgarian and Serbian believers according to the British press, without propaganda. Malinov had publicly condemned entrance of Bulgaria in the war on the side of Central Powers and predicted its catastrophe in 1915. After completing Medical studies in 1920, he left the priesthood and Bulgarian-Macedonian brotherhood „Pravda“, while supporting Alexander Stamboliyski's politics and Yugoslavism. Having left the priesthood of the Bulgarian church, he became member of Russian Orthodox Church Abroad. In 1924, General Consul in Montreal Anto Seferović was not immediately convinced in his honest desires for South Slavs cooperation and warned Božidar Marković to be careful in contacts with Malinov. AY, 341-41 B. M. Marković to the General Consul of the Kingdom of Serbs, Croats and Slovenes in Montreal, Toronto from $22^{\text {nd }}$ May 1924; AY, 371-44-59, 456.

141 AY, 414-8-17 Secretary of Legation in Washington Branko Adžemović to the General Consul in Chicago Radoje Janković, 27 ${ }^{\text {th }}$ February 1928; Boža M. Marković to the Consulate of the Kingdom of Serbs, Croats and Slovenes, Toronto from $28^{\text {th }}$ February 1928; AY, 341-41 B. M. Marković to the General Consul of the Kingdom of Serbs, Croats and Slovenes in Montreal, Toronto from $22^{\text {nd }}$ May 1924.

142 AY, 341-23-53 General Consul in Montreal Anto V. Seferović to the Legation in London, Conf. No. 827 from $6^{\text {th }}$ March 1928.

143 Stoyan Omrachevski was born in 1885, graduated philosophy and law on the University of Sofia. He was member of the BANU since 1905, Minister of Agriculture in the Cabinet of Alexander Stambolisky; member of Managing Board of the BANU 1925-1926 and Managing Board of the BANU "Orange" since 1926. His political activity was recognized as destructive by Yugoslav Ministry of Foreign Affairs in 1927. AY, 371-34-45, 107, 108; Луиза Ревякина, Коминтернът и селските партии на Балканите 1923-1931, София, 2003, 456. 
$1928 ;{ }^{144}$ officially at Carnegie's invitation to attend an international conference at Teachers College at Columbia University. ${ }^{145}$ However, his activities confirmed suspicions that he had been sent by Bulgarian government to parry propaganda for Bulgarian-Yugoslav unification. ${ }^{146}$ The MPO started to oppose Konstantin Todorov more aggressively. During the second half of March and at the beginning of April, he gave speeches in Akron, Pittsburgh, Cleveland, Detroit and Indianapolis. Although Serbian organisations reported that his lectures were positively affecting Macedonian emigration, several incidents took place. ${ }^{147}$ The MPO was sending the same group of members to attend assemblies with the task of starting quarrels or even fights. Konstantin Todorov received information on planned assassination in Detroit, since there was no death penalty for murderers in Michigan. ${ }^{148}$ His lecture was cut short either to avoid killers or due to an incident with communist leader Tsekov who accused him of receiving 8,000 \$ from Vojislav Marinković and Konstantin Todorov slapped him in front of the audience. ${ }^{149}$ Assembly in Akron was attended by 120 MPO members and the speaker once more had to shorten his speech with remark that their leaders will be prosecuted as traitors. ${ }^{150}$ Later, he recommended to Vojislav Marinković to open honorary consulates in Pittsburgh and Akron. ${ }^{151}$ Konstantin Todorov mentioned in his memoirs that during these gatherings he was always guarded by a Serb from Herzegovina who ran a speakeasy in Chicago. "He was enormous and extraordinarily powerful and when at the meetings he rose with clenched fists and glared at hecklers they usually lost interest in expressing their dissent."152

\footnotetext{
144 AY, 371-35-46, 229.

145 AY, 371-35-46, 237.

146 AY, 371-35-46, 257.

147 AY, 371-35-46, 230; AY, 414-8-17 Branko Dajičić to Dušan [Silaški], Pittsburgh 20 $0^{\text {th }}$ March 1928; AY, 449-13-27 General Consul in Chicago Radoje Janković to Vlajko Lugonja, Chicago $20^{\text {th }}$ March 1928; AY, 449-13-27 Vlajko Lugonja to the General Consul in Chicago Radoje Janković, Detroit $20^{\text {th }}$ March 1928; AY, 414-8-17 clipping “Предавање у Акрону”, Српски дневник from 21 $1^{\text {st }}$ March 1928; AY, 449-13-27 Kosta Todorov to the General Consul in New York Đorđe Todorović, Akron 27 ${ }^{\text {th }}$ March 1928; AY, 414-8-17 clipping “Г. Тодоров у Индианополису", Србобран from $29^{\text {th }}$ March 1928; AY, 414-8-17 clipping “Важно предавање”, Србобран from 29 $9^{\text {th }}$ March1928; AY, 414-8-17 announcement “Предавање у Питсбургу”; AY, 414-8-17 President of the SlogaSrbobran in Pittsburgh Dušan Silaški to the General Consul in Chicago Radoje Janković, from 29 ${ }^{\text {th }}$ March 1928; AY, 414-8-17 P. Bulatović to the General Consul in Chicago Radoje Janković, Detroit 29 $9^{\text {th }}$ March 1928; AY, 414-8-17 clipping “Успело предавање”, Србобран from $3^{\text {rd }}$ April 1928.

148 AY, 414-8-17 Kosta Todorov to the General Consul in Chicago Radoje Janković, Mihaljevic Bros. Steamship Agency, Clevelland.

149 AY, 414-8-17 Kosta Todorov to the General Consul in Chicago Radoje Janković, Detroit $7^{\text {th }}$ April 1928.

150 AY, 449-13-27 Kosta Todorov to the General Consul in New York Đorđe Todorović, Akron $27^{\text {th }}$ May 1928.

151 AY, 414-8-17 President of Sloga-Srbobran Dušan Silaški to the General Consul in Chicago Radoje Janković, $29^{\text {th }}$ March 1928.
}

152 Quoted from American edition: K. Todorov, op. cit., 227, 228. 
Konstantin Todorov continued informing the American public about his ideas and IMRO's actions on Yugoslav soil through the press. Professor Mihajlo Pupin helped him publish the article "The King and the Peasant: A glimpse of the Life of the Great Popular Bulgarian Chief Alexander Stambolisky" in Scribner's Magazine in the May 1928 issue. With support of Foreign Affairs Review editor Hamilton Fish Armstrong, ${ }^{153}$ Konstantin Todorov achieved utmost success in the American press by publishing the article "The Macedonian Organisation Yesterday and Today" in the April 1928 issue. ${ }^{154}$ As permanent correspondent of The New York Evening Post Konstantin Todorov published "The Peace in the Balkans" in The New York Times in August 1928. ${ }^{155}$ Konstantin Todorov had continuous contacts with eminent Americans who communicated with Jordan Chkartov and Lambo Kiselinchev. He started correspondence with President of International Committee for Political Prisoners Roger Balduin, through whom the MPO had sent memorandums on Yugoslav terror inflicted upon the Macedonian minority and state of their minority rights to international organisations. Konstantin Todorov introduced him with the IMRO responsibility for the murder of over 25,000 Bulgarians and financial support received from Italy, stating that there were no political emigrants in Bulgaria. He had intended to visit Frank Kellogg and American senators Edward John King and William Edgar Borah, but the mission was unexpectedly terminated and he only sent them one copy of the article published in Foreign Affairs Review. ${ }^{156}$

Although Konstantin Todorov had achieved several results during his mission, he was interrupted by an unpredicted event. A strong earthquake had stricken Bulgaria, causing a large number of casualties and great material damage, and political propaganda in changed ambiance could produce only counter effects. Therefore, American-Yugoslav Society in New York, state and local authorities in the Kingdom of SCS and the Serbian Orthodox Church started

153 Hamilton Fish Armstrong had a number of friends among influential American statesmen and diplomats, was friend with Serbian Plenipotentiary Minister in Washington Slavko Grujić and his spouse Mabel Grujić, supported Serbian propaganda missions in the USA in 1912 and 1917. He had obtained post of Military Attaché in Belgrade in 1919. He traveled to Europe annually, always visiting Yugoslavia and established personal relations with King Alexander I. He was elected by the Council on Foreign Relations for editorial of the Foreign Affairs Review and published a number of articles defending Yugoslav Foreign and Internal policy. He was a member of Executive Board of the American-Yugoslav Society, since its founding in 1924. He criticised Italian politics in the Balkans and Italian financial support to the IMRO. AY, 37116-22, 115, 131, 132; AY, 371-75-98, 31, 39, 40, 200-203; The East-West Discourse: Symbolic Geography and Its Consequences, (ed. Alexander Maxwell), Bern, 2011, 95-107; Hamilton Fish Armstrong, "Italy, Yugoslavia and Lilliputia”, Foreign Affairs, Vol. 6, No. 2, (Jan., 1928), 191-202.

154 AY, 449-13-27 General Consul in New York Đorđe Todorović to the General Political Direction of the Ministry of Foreign Affairs, Conf. No. 84 from $7^{\text {th }}$ May 1928.

155 AY, 371-35-46,229, 230, 290; AY, 449-11-25 General Political Direction of the Ministry of Foreign Affairs to the General Consulate in New York, III Conf. No. 2765 from $22^{\text {nd }}$ June 1929.

156 AY, 371-35-46, 233, 238, 258; AY, 449-13-27 General Consul in New York Đorđe Todorović to the General Political Direction of the Ministry of Foreign Affairs, Conf. No. 84 from $7^{\text {th }}$ May 1928. 
simultaneous fund raising for victims coinciding with the ideas of South Slav unity, propagating that Bulgarians are an ethnical part of Yugoslavs. ${ }^{157}$ In the end, General Consul in New York Đorđe Todorović proposed to the Ministry of Foreign Affairs that Konstantin Todorov should return once again to North America and continue his work on the organisation of Yugoslav-Bulgarian societies. ${ }^{158}$ After Konstantin Todorov departure, General Consul Radoje Janković sent his confidant and decorated war hero Anđelko Mandušić to Pittsburgh, Detroit and Sent Louis to organize branches of the Committee for Yugoslav-Bulgarian unification, but he could not gather a significant number of Macedonians. ${ }^{159}$

After the mission was terminated, Ministry of Foreign Affairs considered propositions of General Consul Radoje Janković and Chargé d'Affaires Branko Adžemović. Yugoslav Foreign Service gradually changed its opinion on the strength of the MPO and their capabilities to accommodate steady support for the IMRO. Therefore, Ministry of Foreign Affairs had resolved to counter the MPO's actions with equal means. First task was assigned to systematic and discrete propaganda through press, assemblies and conferences in the USA and focusing attention on American correspondents in the Balkans. Second aim was activity of the Permanent Committee for Unification of South Slavs in North America. As third objective, Ministry ordered Yugoslav representatives to send lists with names of all Macedonian emigrants and instructed General Consulate in Chicago to infiltrate confidential persons in the ranks of the MPO to collect incontrovertible evidence on their anti-Yugoslav work in order to ask support from the American government. ${ }^{160}$

Comparison of analyses and propositions presented by Božidar Purić in November 1922 and Radoje Janković in March 1928, and decisions made by Ministry of Foreign Affairs in June 1928, indicate key issues observed and development of basic assumptions in the line of work of Yugoslav Foreign Service toward the Macedonian Diaspora. According to Božidar Purić's plan, the principal means was to counter IMRO's terror with equivalent terroristic actions by Yugoslav authorities; while it was listed fourth out of five points as proposed by Radoje Janković; although both general consuls were considering "strong-arm" policy as the most suitable to the Macedonians. There were not

157 AY, 449-13-27 General Consul Đorđe Todorović to the General Political Directory of the Ministry of Foreign Affairs, Conf. No. 81 from 30 ${ }^{\text {th }}$ April 1928; Britanci o Kraljevini Jugoslaviji. Godišnji izveštaji Britanskog poslanstva u Beograd 1921-1938, Knjiga prva (1921-1930), (prir. Živko Avramovski), Beograd-Zagreb, 1986, 504.

158 AY, 371-35-46, 245; AY, 449-13-27 reports of General Consul in New York Đorđe Todorović sent to the General Political Directory of the Ministry of Foreign Affairs, Conf. No. 81 from $30^{\text {th }}$ April and Conf. No. 84 from $7^{\text {th }}$ May 1928.

159 From preserved sources it is not clear what the cause was: opposition of the Macedonian Diaspora to the idea of South Slav Unity, Serbian ethnic origin of Anđelko Mandušić or bad relations between General Consul and his confidant. AY, 449-16-39 General Consul in New York Radoje Janković to the Executive Department of the Ministry of Foreign Affairs, Conf. No. 225 from $16^{\text {th }}$ December 1929.

160 AY, 371-35-46, 279-281. 
many Macedonian and Bulgarian emigrants willing to cooperate with Serb and Yugoslav representatives in 1922, so they were the least of concerns mentioned in the fourth point of Božidar Purić's plan. However, successes achieved over the years in that line of work increased their importance and Macedonian confidents were one of the main concerns for Radoje Janković in 1928.

\section{Conclusion}

During 1920s Yugoslav authorities were more than focused on neutralizing guerrilla and terrorist actions in South Serbia and pro-Bulgarian Macedonian propaganda abroad. State institutions were tracing evidence of IMRO's financial transactions in order to put a halt to money transfers to Bulgaria as a mean of preventing subversive guerrilla activities on Yugoslav soil or at least to use diplomatic channels to circulate information on countries and organisations involved in sponsoring activities on disintegration of what was perceived as collective security in Europe. Since 1922, Yugoslav authorities had strong reasons to believe that Macedonian Diaspora in North America was a very important source of IMRO's incomes. Therefore, Yugoslav state institutions focused their activities on redirecting American Macedonians away from influence of the revolutionary organisation. Yugoslav Foreign Service encountered several problems in North America: broadly organised Bulgarian-Macedonian propaganda; non-existing contacts between Serbian and Macedonian Diaspora and lack of funds available for intelligence activities. General Consulate in Chicago was the most active and successful among Yugoslav diplomatic-consular missions in North America in counteractions against Bulgarian-Macedonian propaganda. In struggle with Bulgarian-Macedonian organizations in North America the Yugoslav diplomatic and consular personnel had to adapt their activities according to American conditions. Free discussion on the neutral and diplomatic ground raised issues of Macedonian ethnicity and statehood, minority rights, Yugoslav and Bulgarian foreign and domestic policies. Therefore, Yugoslav authorities continued to implement "strong-arm" policy in South Serbia, and applied "soft power" diplomatic methods toward Macedonian Diaspora in North America. This meant that Yugoslav diplomaticconsular representatives could not directly confront emigrant organizations yet they were trying to infiltrate informers in their ranks or win over their activists, trying to provoke intervention of American and Canadian authorities against Bulgarian-Macedonian Diaspora political activity and create new propaganda approaches. Yugoslav Foreign Service had to seek support from the Serbian Orthodox Church in countering activities of anti-Yugoslav orientated Diasporas and Bulgarian priests. More aggressive Italian politics which included closer cooperation with the IMRO, in late 1926 and early 1927, was a new stimulant and the Kingdom of SCS started broader counteraction with new diplomatic- 
consular personnel. As a result Bishop Nikolaj Velimirović and Konstantin Todorov were sent to unofficial diplomatic-propaganda missions.

During Konstantin Todorov mission, the idea of Bulgarian-Yugoslav unity was elaborated and accepted as new propaganda approach toward Macedonian Diaspora. One of the main concerns in the work of Yugoslav Foreign Service was how to deal with almost a complete segregation of Macedonian Diaspora from Serbian and Yugoslav emigration communities; in addition, they were more than weary of Serbian, Bulgarian and Greek propaganda. Political platform which promoted Bulgarian-Yugoslav unity was developed as intermediary means to secede Macedonians from the MPO and the IMRO influence and to gradually attract them to South Slav idea, i.e. Yugoslavia. Successful advertisement of this idea was supported by respected members of Macedonian Diaspora in the USA and Canada, former members of the Central Committee of Bulgarian-Macedonian Committee Pavle Angelov and Dimitry Malinov, predecessors of David Nakov and Krsto Tsenov. Established Permanent Committee for Bulgarian-Yugoslav Unification in Chicago was promoting ideas of cooperation instead of diversities and conflicts, characteristic for Serbian/Yugoslav and Bulgarian propaganda. One of the most important collaborators in Konstantin Todorov's mission was a former member of the organization "Unification or Death" and then General Consul Radoje Janković. Yet, it is indicative that the crucial goal of the mission was to oppose Italian and not the IMRO's and the MPO's activity. This could be an important lead to answer the question why Canada was not in the focus of the Konstantin Todorov, although the MPO had one of the most important strongholds in Toronto. Unexpected termination of Konstantin Todorov's mission and unsuccessful attempt of Radoje Janković to establish new branches of the Committee for Yugoslav-Bulgarian Unification in three cities, during 1928, raising the question whether several-month mission was not sufficient to suppress Bulgarian-Macedonian anti-Yugoslav propaganda or this idea could be promoted only by Bulgarians or Macedonians among Macedonian Diaspora. Author of this article was not able to give an answer to this question based on preserved records of the Yugoslav diplomatic-consular missions in the USA. 


\title{
Резиме
}

Срђан Мићић

\section{Мисија Константина Тодорова у Северној Америци 1927-1928: Рад југословенске дипломатско-конзуларне службе против македонско-бугарских организација у Северној Америци}

\begin{abstract}
Апстракт: Централна питања у југословенско-бугарским односима током међуратног периода били су тзв. македонско питање и субверзивни рад ВМРО. Од почетка двадесетих година, југословенска спољна политика је обухватала и систематску акцију против бугарске пропаганде и организација у Северној Америци које су биле подређене ВМРО. Југословенска дипломатско-конзуларна служба је имала искуства са пропагандним активностима Бугарске, али је морала да пронађе нове методе, применљиве у друштвима Сједињених Америчких Држава и Канаде, јер су у те две државе живели бројни македонски исељеници. Мисија Константина Тодорова је имала велики значај у дефинисању засебне северноамеричке стратегије за сузбијање антидржавног рада пробугарски оријентисаних Македонаца.
\end{abstract}

Кључне речи: пропаганда, емиграција, југословенско-бугарски односи, македонско питање, ВМРО

Један од озбиљних проблема за Краљевину Срба, Хрвата и Словенаца током 20-их година XX века била је активност Унутрашње македонске револуционарне организације (ВМРО). Југословенски државни органи су посебну пажњу посветили онемогућавању дотока финансијских средстава из Северне Америке, која су слале бугарска и македонска дијаспора. Основни проблеми у контраакцији били су непостојање комуникације између Срба и Македонаца и ограничавајући фактори ангажовања Српске православне цркве у Сједињеним Америчким Државама и Канади. Мисија Константина Василева Тодорова је била организована у ширем склопу југословенских активности против продора италијанског утицаја на Балканском полуострву. Његов боравак је имао велики значај за разбијање 
јединства бугарске и македонске дијаспоре у Северној Америци, јер је успео да пропагира идеју југословенско-бугарског зближења и уједињења. Основна идеја је била приближавање Македонаца јужнословенској солидарности, која би постепено утрла пут њиховој лојалности према југословенској држави. Константин Тодоров је успео да придобије угледне чланове македонске и бугарске дијаспоре и оснује Стални комитет за југословенско-бугарско уједињење у Чикагу, који су подржали поједини Бугари и Хрвати. Југословенска дипломатско-конзуларна служба у Северној Америци је доживела неуспех у покушају да настави његову мисију. 